\title{
The recycling of material culture today and during the Paleolithic
}

\author{
Daniel S. Amick \\ Department of Anthropology and Institute for Environmental Sustainability, Loyola University \\ Chicago, USA
}

\begin{abstract}
Archaeologists are being increasingly challenged to apply their methods and perspectives to address contemporary global concerns, such as material consumption and recycling. The archaeological investigation of recycling can contribute to understanding its behavioral causes and situational contexts because it can reveal systematic patterning in its temporal, spatial, and formal dimensions. In this paper, I review some of the archaeological evidence of artifact recycling and a few lessons drawn from those studies, including general patterns in lithic recycling behavior and needs to address ambiguity in the definition of recycling, compounding factors of equifinality in lithic reduction, and recognizing opportunism in recycling behavior. This evidence is also used to consider the behavioral and environmental circumstances of patterned recycling in the broader study of material culture and human behavior. It is argued that archaeological studies can offer useful contributions to such universal theories and that archaeological explanations about recycling behavior would benefit from greater integration with the larger body of historical and social science studies on this topic.
\end{abstract}

Keywords: lithic technology, artifact recycling, double patina, obsidian hydration, recycling history, archaeological relevance

\section{Introduction}

Media reports about "The Origins of Paleolithic Recycling" conference emphasized the substantial time depth of recycling behavior and promoted the idea that it illustrated long-term continuity in this aspect of human behavior (e.g., David 2013, Ross 2013). This paper offers a review of recycling behavior throughout human history in order to identify and evaluate the factors which seem to motivate it. It begins with a discussion of recycling today and during the historical past. Then it describes critical terminological distinctions involved in the processes of recycling and reclamation. Examples of prehistoric recycling and reclamation are then reviewed followed by specific discussion of how these processes can be identified among lithic artifacts. A few case studies from North America are then presented which illustrate how recycling and reclamation processes are important to increasing our understanding of the archaeological record. This paper concludes with a few comments about the challenges and opportunities artifact recycling presents to archaeology and discussion of the relevance of these long-term views for understanding the factors which condition recycling behaviors.

Material objects are often reused, recycled, and reclaimed in a variety of ways. The most robust considerations of these transformative processes are found in the work of Michael Schiffer (1972, 1976, 2010, Schiffer et al., 1981). In particular, he has carefully distinguished several kinds of "reuse processes" based on changes in object use, object user, and the form of an artifact (Schiffer 2010, pp. 32-34). Schiffer's reuse processes are restricted to cases in which the object has not yet entered the archaeological record, in his terminology, the object remains in 
"systemic context" although its use, form, or user may have changed. He recommends that in cases where artifacts have been retrieved from the archaeological record and bought back into a living systemic context, we consider them as having been transformed by what he calls the "reclamation process" (Schiffer, 2010, p. 38).

\section{Contemporary and historical patterns of recycling}

Significant historical shifts away from the age-old tradition of artifact mending, repair, recycling, and repeated reuse began around the beginning of the 20th century (Cooper, 2005; Miller, 2000; O'Brien, 2008; Strasser, 1999). Interestingly, evidence from the field of historic archaeology commonly identifies these traditions in the archaeological record, for example, the frequent recycling of containers such as barrels (Ross, 1985) and bottles (Adams 2002b, Busch, 1987; Stuart, 1993; Wilson, 1995). Motloch (2003, p. 228) reports that between 1850 and 1910 several dozen book-length manuals were published which offered instructions on how to recycle a wide range of household objects. Historians and environmentalists have lamented this change toward overconsumption which accelerated during the beginning of the industrial age of mass production. This transformation caused the shift from mending and repairing to a form of recycling that is best termed downcycling in which discarded objects are broken down to raw product and manufactured again as new objects (Grogan, 1996; Matos and Wagner 1998). The only event that seemed to slow this trend was the conservation and recycling movement associated with the allied war effort in WWII (Cooper, 2008; Riley, 2008). This success in motivating recycling behavior among consumers in the developed countries reflects how the individual decision to recycle today is largely connected with ideological and political viewpoints (Best and Mayerl, 2013; Hornik et al. 1995; Kaiser et al. 1999; McGuire, 1984). Secondarily, the citizens of developed countries are more motivated to sort waste for recycling purposes when it is made more convenient for them (Derkson and Gartrell, 1993; Hornik et al., 1995; Schultz et al., 1995; Vining and Ebreo, 1990). These modes of contemporary recycling behavior actually refer to waste sorting rather than recovery and reclamation of discarded materials.

Today, the most common situations where individuals in the world's developed countries participate in the recovery of discarded materials are among the marginalized and within the lowest socioeconomic classes (Gowan, 1997; Simpson-Herbert et al., 2005; Tremblay et al., 2010; Underwood, 1993). In many cases, the opportunity for individuals to participate in the reclamation of waste in affluent countries has been removed because of formal recycling programs which frequent ship waste to developing countries for downcycling and product remanufacturing, usually making new products that are sold back to consumers in the developed world (Grossman, 2006; Van Beukering and Curleed, 1998; Van Beukering and Boumann, 2001). Systematic mining of landfills for desirable resources is already occurring because of resource scarcity facing certain developed nations and it is expected to increase in the future (Krook et al., 2012; Quaghebeur et al., 2013; van der Zee et al., 2004).

Examples of contemporary scavengers who reclaim, reuse and recycle a significant portion of their food and material possessions are rare and expectably represent the poorest of the poor who are living in the Third World (e.g., Abad, 1991; Keyes, 1994; Medina, 2007; Ocasiones et al. 2009). Such developing countries remain some of the last places to witness individuals making significant efforts to reclaim and recycle materials for reuse, and more often than not, these individuals (usually termed scavengers or waste pickers) are simply working as 
informal labors and selling materials to brokers who relay them on to industry for downcycling (Medina 2007). The growing demand for materials by industries and products by consumers living in developed countries has resulted in an organized system of materials scavenging and recycling in much of the developing world where individuals and guilds participate in collecting and selling scrap to middlemen who make most of the profit (Adama, 2012; Adeyemi et al., 2001; Asmin et al., 2012; Groethues, 1988; Hayami et al., 2006; Medina, 2007; Moreno-Sanchez and Maldonado, 2006; Rockson et al., 2012; Scheinberg, et al., 2011;Schenck and Blaauw, 2011; Vergara and Tchobanoglous, 2012). Currently it is estimated that around 140 million people (about $2 \%$ of the world's population) make a living by collecting, sorting, using and selling scavenged material from discarded refuse as a consequence of poverty and hardship (Medina, 2007). Many of those involved as scavengers are women and children (Davies, 2008; Gunn and Huysman, 1994; Ostes, 1992) who tend to suffer from numerous health problems associated with this hazardous work - sometimes involving toxins - and because they live near the dumpsites to reduce material transport costs (Afon, 2012; Binion and Gutberlet, 2012; Grossman, 2006; Hunt 1996; Kimbugwe and Ibitayo, 2013; Ocasiones et al., 2009). Buyers come directly to the settlements near the dumps to buy the salvaged materials from the scavengers. Similar systems of materials recovery from landfills by the poor were common in large cities in the U.S. during much of the 19th and early 20th centuries (e.g., Miller, 2000; Pellow, 2002).

Political economists argue that public concerns about recycling in the developed world are largely the result of desires to assuage guilt about our increased rates of consumption and waste resulting from affluence and too many products with short use-lives (Hawkins, 2006; MacBride, 2012). As the archaeologist Gavin Lucas (2002, p. 15) has expressed it, "recycling can be seen to have taken on a reconciling role, resolving the dilemma of disposability: recycling permits a disposable material culture yet at the same time counteracts the apparent wastefulness in such a practice. But the ideology of recycling may be out of all proportion to its efficacy and experience in practice; surveys of attitudes to recycling show how people want to recycle more, but at the same time, do not do so - the reasons given tending to be laziness, business, forgetfulness or inconvenience." History shows that government and industry have generally been very reluctant supporters of recycling - largely because it cuts into the profits to be gained by using virgin materials and this problem is especially true of glass and paper (Humes, 2012; MacBride, 2012; Rogers, 2005). While we would like to think that most people today are concerned about the growing overconsumption of earth's resources, resource extraction industries tend to treat them as common pool resources easily depleted unless protected by regulations on exploitation rates (Borgerhoff Mulder and Coppolillo, 2005; Feeney et al., 1990; Hardin, 1968; Ostrom, 1999).

This review of historical and contemporary recycling behavior suggests that archaeological considerations of recycling behavior tend to be focused on different concerns. For the most part, recycling to those in the developed world is simply waste sorting which is a job that governments and industry have offloaded onto the public to counteract the increased costs that dealing with materials recycling has on industry profit margins (Dean, 1995; Eckelman and Chertow 2009). One modern business solution to this problem has been to ship recyclable materials from the developed countries to the developing countries where labor costs are lower and environmental protections are weaker (e.g., Grossman, 2006). As a result, waste and recycling today have simply become vehicles in the globalization of inequality.

\section{Reclamation and recycling in the archaeological record}


Modern examples of recycling generally do not involve reclamation over substantial amounts of time and rarely involve retrieval from archaeological context. Usually recycling today follows shortly after the use and discard of an object, but it can involve a functional change in the product and nearly always involves a change in the user. As such, it conforms best to Schiffer's (2010, pp. 32- 34) description of lateral recycling (change in artifact user or social unit of use), secondary use (change in object's use but not form), or recycling (manufacturing change in an artifact's form). These analyses recommend distinguishing retrieval and recycling of an object from archaeological context as reclamation rather than recycling (Schiffer, 2010, p. 38).

Archaeologists have documented evidence of lithic reclamation for more than a century, often through the phenomenon known as "double patina" in which weathered artifacts are picked up and flaked again by later artisans (Martin, 1906). The absolute time depth of reuse, repair, and reclamation activities is uncertain, but double patina appears in a few Lower Paleolithic Mode 1 assemblages of Southern Europe and the Near East. Table 1 compiles many of the sites where lithic recycling has been reported. It is possible that sites have been inadvertently omitted from this list, but it is probably representative of the long-term temporal distribution of lithic recycling activities. The earliest reported assemblage, estimated to be $1.3 \mathrm{ma}$, is represented by the Mode 1assemblage from Fuente Nueva 3, Spain (Toro-Moyano et al. 2009). The next youngest example of recycling is the MIS11 Mode 1 lithic assemblage from Dealul Guran, Romania estimated at 420-360 ka (Iovita et al., 2012), followed by the Amudian assemblage from Qesem Cave, Israel dating from approximately 400-200 ka (Barkai et al., 2009). The frequency of double patina in the Dealul Guran assemblage is remarkably high at $6.5 \%$. What is most notable about this list is the relatively high frequency of recycling in Late Acheulian and Middle Paleolithic assemblages, especially those found in the arid regions of North Africa and the Near East. At Givat Rabi East, a Middle Paleolithic knapping site in the Lower Galilee of Israel, double patina appears on $63 \%$ of the cores and $60 \%$ of the tools and debitage, and triple patina (presumably representing at least two reclamation episodes) is found on $28 \%$ of the cores and 33\% of the tools and debitage (Ekshtain et al., 2012). One noteworthy Aterian assemblage (SJ-00-57) in Libya has been documented to contain 22\% double patinated artifacts (Spinapolce and Garcea, 2013).

While double patinas are reported at a few Upper Paleolithic and later sites, the number of Middle Paleolithic assemblages with evidence of recycling and the frequency of recycling in those assemblages beg explanation as a well-documented phenomenon. Equally interesting is the apparent absence of recycling evidence in many sub-Saharan African or Lower Paleolithic assemblages. This pattern is even more intriguing given the tendency for site reoccupation and surface exposure of discarded but still useful cores and tools at many locations such as Olorgesailie (Isaac, 1977). Although the reason for this apparent shift toward increased recycling during the Late Acheulian may have multiple causes (including environmental conditions of surface exposure), it seems that Middle Paleolithic toolmakers took greater advantage of the opportunities for scavenging discarded debris encountered through site reoccupation and land use redundancy (Thiéaut et al., 2010). Porraz et al. (2013, p. 3383) recently observed that fine-grained stone tools were the most likely to exhibit double patina at the South African Middle Stone Age site of Diepkloof Rockshelter, which corresponds to expectations about increased recycling of more highly-valued materials. This hypothesis is worth testing among other assemblages where double patina is present. Overall, it is surprising 
there is not greater evidence of lithic recycling in the archaeological record, but this problem may only be a function of our limited abilities to accurately detect it.

A substantial problem for recognizing lithic recycling is the subtractive nature of this technology in comparison with other technologies. In lithic technology, products are always become smaller and smaller through use-wear, resharpening, rejuvenation, and recycling. As a result, the potential to make new products from discarded materials is very limited. It is also worth considering the wide variety of examples of material reuse and recycling documented in the archaeological record. Several ethnographic and archaeological studies have identified the stockpiling of discards as an indicator of reuse and recycling behaviors (Bradley, 1988; Chang, 1988, 1991; Hayden and Cannon, 1983; Kamp, 1991; Pettegrew, 2002; Plunket and Uruñuela, 2005; Rathje et al., 1992). Other studies have documented that systematic scavenging and reclamation can commonly occur at abandoned structures (Cameron, 1990, 1991; Diehl, 1998; Tomka 1993). Reclamation and reuse of architectural elements has been recognized to affect the archaeological record from Neolithic to historic times, including the scavenging of stone blocks, religious monuments, timbers, boards, and fasteners (Adams 2002a; Faulkner, 2004; Horne 1991; Kent, 1990; LeRoux, 1984; Pozorski and Pozorski, 2005; Richter, 2009). The long-term preservation and reuse and recycling of "old wood" for construction and fuel has long been recognized to present challenges to interpretation of the archaeological record in arid environments (Dean, 1978; Schiffer 1986). Ancient recycling of ceramics includes an especially wide range of uses found for broken and discarded pottery, including crushing them for use as temper in making new ceramics and mud bricks (Deal and Hagstrum, 1995; DeBoer and Lathrap, 1979; Fontana, 1998; Lister and Lister, 1981; Nodarou et al., 2008; Orton and Hughes, 2013, pp. 164-165; Peña, 2007; Shepard, 1956, pp. 26-31, 156-168; Siegel and Roe, 1986). It has also been widely recognized that ancient glass makers frequently melted older glass artifacts and reconstituted them as new vessels (Bugoi et al., 2013; Degryse et al., 2006; Foster and Jackson, 2010; Silvestri, 2008; Silvestri and Marcante, 2011).

The emergence of metallurgy ushered in a new technology that ultimately led to the decline of stone tool technologies (Rosen, 1996). One of the critical advantages that metal working provided over lithic technology was the ability to combine and reforge broken and exhausted tools to make new ones. Recycling has been documented throughout the world for the metal industries of ancient copper (Bourgarit and Thomas, 2012; Bray et al., 2012; Potts, 2007, p. 126-128; Simmons and Shugar, 2008), bronze (Bradley, 1988; de Ryck et al., 2005; Figueiredo et al., 2010; Needham et al., 1989; Ottaway and Roberts, 2008), and iron (Lahiri, 1995; Zimring 2005, pp. 12-36). Bradley (1988) has argued that shortages of bronze lead to increased recycling and eventually to the adoption of iron technology. During the early 4th century CE, Roman Britain experienced an extreme unavailability of smelted metal as a result of the faltering political power of Rome and people resorted to scavenging, stockpiling, and reworking of metal objects (Fleming, 2012, p. 9). This pattern differed significantly from the organized and systematic methods of metal recycling during the height of Roman political and economic power. Even today, the cost of metal extraction and refining and manufacture is still high enough that metal recycling remains one of the most profitable of all material recycling industries (Wernick and Themelis, 1998).

The shift from stone to metal tool technology and the adoption of glass (and now plastic) containers appears to represent a significant change toward recyclable materials in the long-term history of human material culture. Likewise parchments have been replaced by paper, another recyclable material which now represents the largest component of human material consumption 
and waste, which as a whole has been rapidly increasing during the past century (Alter, 1991; Bridgewater, 1985; Denison, 1996; Durning, 1996; Humes, 2012; Krausmann et al., 2009; Leonard, pp. 51-56; MacBride, 2012; Rathje, 1978, 1979, 1997; Rathje et al., 1992; Rathje and Murphy, 1992; Rogers, 2005; Van Beukering and Bouman, 2001; Zimring, 2005).

Ethnographic cases of artifact scavenging and recycling are usually found in arid environments where surface exposures of archaeological deposits are widely available for reutilizing (reviewed in Amick, 2007, pp. 225-227). In fact, given the stability of many surface exposures of archaeological deposits in such situations around the globe, it is surprising that archaeologists have not reported more cases of recycling. The infrequency of documented recycling is most likely the result of its low visibility when double patination is not evident. The problem of requiring double patinas to identify recycling is that not all artifacts patinate equally and not all environments are conducive to patina formation. In addition, if an artifact is reclaimed from the archaeological record and not modified (which would reveal its recycling history), then it might not be recognized as having been scavenged from an archaeological deposit. For example, Judd (1954) documented a Folsom spear point at Pueblo Bonito in Chaco Canyon from his fieldwork there in the 1920s. Because this find occurred prior to the demonstration of the Pleistocene age of Folsom points, he failed to recognize its significance as a probable case of prehistoric artifact reclamation. A similar find of a Folsom point has been reported from the floor of an historic period Navajo hogan (Peckham 1980). Cushing (1883) illustrated how the Zuni Pueblo peoples collected ancient projectile points to be incorporated in their fetishes used for ceremonial purposes.

Most discussions of ethnographic accounts on the collection and recycling of artifacts have focused on their implications for potentially misinterpreting the archaeological deposits in which they were found. Several have cautioned how such artifacts have the potential to affect chronological assessments and assemblage composition (e.g., Ascher, 1968; Camilli, 1988; Camilli and Ebert, 1992; Diehl, 1998; Gould et al., 1971; Hildebrandt, 1978; Schlanger, 1991, pp. 460-474; Simms, 1983; Vaquero, 2008; Wilk and Schiffer, 1979). In general, these archaeological discussions have taken the perspective that recycling is a source of bias that diminishes the integrity of the archaeological record rather than considering it as a behavioral phenomenon worthy of investigation and explanation in its own right. While these concerns are justified, they also fail to recognize that artifact recycling may be telling us something worthwhile about the behavior and situational context of those involved in the recycling. For example, I provide a few examples below of artifact recycling encountered in my own research and offer some suggestions about the meaning of that evidence (see Fig. 1 for study locations).

\section{Lithic artifact reclamation and recycling case studies}

\subsection{Analytical framework for understanding variation in recycling behavior}

Chipped-stone technology is recognized to have a variety of ways of extending use-lives of objects through resharpening, rejuvenation, and recycling. This analysis expands on my previous consideration of the topic of lithic recycling in terms of both behavioral causes and archaeological effects (Amick, 2007, 2014). As Schiffer (2010, p. 38) and others have noted, it is not always easy to distinguish artifact reclamation from artifact reuse in the archaeological record, much less to distinguish different kinds of reuse processes. This challenge was documented in my earlier writing and rises in this one as well. In particular, I suggest the 
elimination of ambiguous cases of artifact recycling when seeking to document and understand reclamation processes. Second, this analysis considers the theoretical role of temporal issues in recycling as a springboard to broader considerations of the recycling behavior of cultural systems in the past and the present. This comparative framework emphasizes that it is important to recognize behavioral and contextual distinctions in recycling activities over time. While the context of contemporary material recycling activities differs greatly from those of the preindustrial past, there are a few interesting similarities which help to define the underlying factors which help regulate recycling behaviors.

\subsection{Archaeological cases in the Fortymile Wash region of southern Nevada}

Long-term compliance archaeology at the Nevada Test Site (NTS) in the Southern Great Basin of the western US has produced several examples of artifact recycling which appear to be related to the gradual depletion of local obsidian resources. These patterns are strongest at the archaeological sites situated on the desert pavements and alluvial terraces surrounding Fortymile Wash, a large but intermittent drainage in a region averaging about $15 \mathrm{~cm}$ of annual precipitation. Localized deposits of secondary obsidian cobbles and pebbles can be found throughout this valley and these places usually have evidence of prehistoric lithic procurement and reduction at them. Alternative materials for the production of stone tools occur in the area, but local obsidian sources were often preferred and served as important locations in the context of general prehistoric land use. The reuse of these obsidian scatters over several thousands of years resulted in a complex landscape of debris from overlapping occupations and activities. This palimpsest pattern of repeated occupations associated with lithic recycling is not uncommon in North American desert regions and appears to be particularly intense at the NTS obsidian source areas.

Projectile points can provide a reliable measure of diachronic shifts in raw material use in this region. Raw material frequencies for a robust sample of projectile points from the NTS are shown in Table 2. A total of $83 \%(n=152)$ of these Early Holocene points are made of obsidian, compared to only $50 \%(\mathrm{n}=218)$ of the Late Holocene points. The main obsidian source locations have been identified from regional archaeological surveys and characterized by trace element studies. X-ray fluorescence sourcing of a sample of 103 obsidian points from the NTS demonstrates the degree to which prehistoric inhabitants were relying on local obsidian deposits. Table 3 illustrates how high frequencies of local obsidian use distinguish both the Early Holocene $(73 \%, \mathrm{n}=41)$ and Late Holocene $(89 \%, \mathrm{n}=42)$ assemblages, but the higher proportion of nonlocal obsidian use during the Early Holocene may suggest greater mobility.

There is an overall preference for obsidian resources in this region, but this resource appears to have been depleted by the Late Holocene. For example, obsidian source locations along Fortymile Wash also contain the densest concentrations of Early Holocene artifacts in the region while Late Holocene occupations incorporate a wider array of landform preferences. As a result, Early Holocene occupants were able to take the largest and best quality obsidian clasts leaving fewer and smaller materials for subsequent inhabitants. Evidence from two large lithic procurement sites at the NTS has provided conspicuous evidence of the depletion of obsidian and chalcedony from the Fortymile Wash alluvial terrace deposits.

At the Midway Valley chalcedony quarry (26Ny4759), I conducted lithic refitting, site spatial analysis, and a systematic evaluation of the unmodified toolstone remaining at this site (Buck et al., 1994). This surface site served primarily as a procurement station for large 
chalcedony blocks, but 24 clusters of obsidian flaking debris were also collected from the reduction of small, rounded nodules. All unmodified toolstone was collected from the site during archaeological recovery, but only two small nodules of obsidian were recorded. This situation illustrates severe prehistoric exploitation of a highly dispersed scatter of small obsidian nodules. Direct evidence of much later scavenging of the Early Holocene debris left at this site is illustrated by a weathered and recycled Early Holocene (Great Basin Stemmed) projectile point (Fig. 2). The stem on this discarded tool exhibits a more recent flake removed during the recycling effort. The largest chalcedony materials at Midway Valley also appear to have been depleted because the unmodified chalcedony blocks still remaining at the site were usually smaller than the discarded cores.

Direct evaluation of obsidian resource exploitation patterns were documented at Buckboard Mesa (26Ny4892), where dense surface scatters of small, sub-rounded obsidian nodules and several lithic workshops were located (Amick et al., 1991). The assemblage at this location primarily reflects initial through intermediate stages of core reduction. Contrary to expectations, the discarded waste flakes found at the Buckboard Mesa quarry are generally larger than the unmodified obsidian still remaining on the surface. Comparison of a size-graded sample of unmodified obsidian clasts versus the waste flakes from the site is documented in Table 4 which shows that $61 \%$ of the obsidian waste flakes were larger than $1.27 \mathrm{~cm}$ mesh, but only $27 \%$ of the unexploited obsidian nodules were that large. This size difference is statistically significant with the remaining obsidian nodules substantially underrepresented in the large size grades and this trend illustrates how obsidian resources were severely exhausted at Buckboard Mesa.

As noted above, local obsidian exploitation at the NTS was heaviest during the Early Holocene, as a result, surficial obsidian resources appear to have been substantially degraded for Late Holocene populations. At Buckboard Mesa, there is additional evidence in the form of recycling older artifacts to support this suggestion. These artifacts commonly contain deep but broad bulbar scars and many flakes possess a large undulation, which often nearly plunges through the core prior to fracture termination. Replicative experiments showed that direct freehand, hard hammer percussion rather than bipolar percussion was used to split these small nodules and cores. This reduction strategy represents an effective means of exploiting small obsidian cores because it minimizes waste and maximizes the production of large flake blanks. Despite the absence of bipolar flaking, 25 (3\%) of the 826 obsidian cores and tools from Buckboard Mesa exhibited double patinas diagnostic of artifact reclamation. Recycling of obsidian artifacts at Buckboard Mesa reflected two primary goals - flake production from older cores (Fig. 3) and small biface production (Fig. 4). Following standard conventions of artifact illustration, the original cortex is represented by stippling and older weathered flake scars are indicated by dashed ripple lines.

Obsidian hydration analysis was used to investigate chronological patterning among these recycled artifacts. The potential of obsidian hydration analysis to evaluate artifact recycling has been used to suggest patterns of artifact recycling at various locations in western North America (Batcho, 1984; Earls et al., 1989; Jackson, 1985; Kaufmann, 1984; Raymond, 1985). These efforts have usually focused on the demonstration of chronological anomalies (deposits containing artifacts with a discordant mixture of hydration band thicknesses) or the measurement of two or more hydration bands of different thickness on a single artifact. For example, Earls et al. (1985) found that many projectile point tips tended to produce younger dates than their corresponding stems. That anomaly was suggested to result from recycling and tip resharpening 
of these projectile points although technological analysis was not pursued to support that suggestion.

At Buckboard Mesa, obsidian hydration analysis was integrated within the framework of technological analysis by measuring hydration bands on the rehydrated flake scars of recycled artifacts. This strategy reduced the potential ambiguities caused by measurement errors and differential weathering. Comparison of hydration band measurements on several hundred chronologically diagnostic projectile points from the NTS recommends an average hydration thickness development rate of approximately one micron per millennium. A systematic sample of 60 artifacts from Buckboard Mesa produced hydration band readings between 7.7 and 1.2 microns with an average of 2.5 microns. These data suggest obsidian exploitation begins at the site in the Early Holocene and intensifies during the Late Holocene.

Obsidian hydration measurements on the rehydrated artifacts provided temporal measurements of the occurrence of recycling. Hydration rims were measured on sequential and adjacent flake scars with differential weathering when found on a common face (to eliminate the known effects of differential hydration rates occurring on opposing surfaces). Comparison of these paired readings shows a range of 0.1 to 3.9 microns (approximately 100 to 3,900 years) separating each recycling event. Fig. 5 presents a bivariate plot of paired hydration rim measurements for these 25 recycled obsidian artifacts identified at Buckboard Mesa. Two artifacts failed to show any difference in hydration band thickness, which may reflect measurement error or recycling event separations of less than one hundred years (approximately 0.1 microns). The analytical need to limit identification of recycled artifacts on the basis of differential weathering probably underestimates the actual amount of recycling that occurred. In addition, recycled artifacts that fail to develop differential weathering (particularly those with minimal chronological separation) are probably underrecognized archaeologically. Furthermore, many scavenging and successful recycling attempts probably removed items from the site.

Despite these analytical limitations, this study suggests that technological preferences for obsidian probably caused Late Holocene groups at the NTS to practice recycling from quarry and habitation localities abandoned by Early Holocene groups. Comparison of hydration rim thicknesses of the recycled artifacts with the local projectile point hydration chronology suggests obsidian scavenging and reworking is frequently associated with the Late Holocene makers of small arrowpoints (i.e., the Rose Spring and Desert Series). Once bow and arrow technology was adopted, the reduction in projectile point size requirements may have encouraged exploitation of previously discarded debris and increased the potential number of suitable lithic sources. In general, the practice of reclamation and recycling of archaeological deposits of obsidian debris during the Late Holocene in Fortymile Wash seems to be linked to declining lithic resources (especially obsidian), adoption of bow and arrow technology, and perhaps other factors associated with changes in technological and settlement organization.

\subsection{Great Basin crescents, recycling, and toolkit alteration}

I have documented another intriguing case of artifact recycling among the unique chipped-stone tools known as Great Basin Crescents. Experimental studies and technofunctional analysis of the distribution and damage patterns on 591 of these artifacts from Terminal Pleistocene lakeshore settings in western North America suggests that open-water hunting of waterfowl may have played a significant role in the subsistence strategies of these pluvial lake foragers in western North America. The majority of this assemblage comes from the 
Ernie Durbin collection at 26-Hu-17. Chipped-stone crescents are generally bifacially flaked tools which are made from high quality cherts, chalcedonies, and jaspers (Justice, 2002, pp. 116125; Tadlock 1966). The damage and wear patterns on these artifacts are most consistent with use as transversely hafted projectile points that were frequently resharpened, repaired, and reused. Crescents often exhibit mild to severe forms of mechanical and chemical weathering resulting from a complex history of littoral dynamics and alkaline desert exposure. Within this large assemblage, I have identified only a few examples with double patina reflecting the intermittent reclamation and reworking of weathered tools (Fig. 6).

A more common pattern of recycling seems to be the modification of Black Rock Concave Base (BRCB) projectile points to reform them as crescent tools. These two artifact types often have identical toolstone preferences and flaking styles suggesting frequent contemporaneity within the same techno-complex. Within this crescent assemblage, I was able to identify 24 (4\%) that had been recycled from BRCB points laterally recycled into crescents (Fig. 7). These observations strongly suggest direct technological relationships between crescents and concave based points which are sometimes recycled to create crescents. What is most striking about these lateral recycling cases is the apparent ruin of complete BRCB points to make crescents suggesting the makers were unprepared for the need to have adequate numbers of crescents in their toolkits. These situations may represent unexpected productive hunting encounters with migratory waterfowl which required toolkit alteration through recycling.

In addition to these cases, crescents were themselves sometimes subject to recycling. A total of 91 of these crescents (15.4\%) exhibited modifications such as beveling to facilitate scraping $(n=66)$, delicate graver tips $(n=23)$, and notches $(n=2)$. Lithic raw materials are limited to distances of at least $25 \mathrm{~km}$ and unexpected needs generally had to be met by altering the transported toolkit. With the exception of the few crescents exhibiting double patina, it seems that most of this recycling activity occurred without artifacts being scavenged from archaeological context.

\subsection{Artifact scavenging and recycling in the Southeastern US}

Archaeological awareness of recycling often occurs when older artifacts are found in what are determined to be later deposits. Fig. 8 illustrates three projectile points diagnostic of the Kirk Corner-Notched Cluster excavated from deeply buried alluvial floodplain deposits at the Cedar Creek Site (40Mu432) on the Duck River in Tennessee. Kirk Cluster artifacts are securely dated between 10,000 and 9,000 radiocarbon years BP at several stratified sites throughout the southeastern US (Chapman, 1985). However, these Early Holocene diagnostics were co-mingled within an archaeological horizon that also contained several stemmed projectile points classified as members of the Sykes-White Springs Cluster known to date 3,000 radiocarbon years younger (Amick, 1985). Initially, this unexpected finding forced questions about security of the radiocarbon age for these two temporal markers as well as possible mixing within the archaeological deposits.

Geomorphological investigations at this site and the surrounding river basin indicated that the overbank sedimentation was relatively gentle with several periods of surface stability and soil formation during the Holocene (Brakenridge, 1984). However, there was no evidence to suggest that regional floodplain surfaces could have lasted for more than several centuries during the Mid-Holocene. Furthermore, alluvial deposits of Early Holocene age that could have contained Kirk occupations were not known in the region. All the dated alluvial sequences in the 
region begin around 7,000 radiocarbon years $\mathrm{BP}$, although it is possible that earlier deposits are deeper than backhoe testing was capable of exposing (limited to about $250 \mathrm{~cm}$ ). Artifact refitting at another nearby mid-Holocene site within the same alluvial regime has shown that archaeological materials can be vertically dispersed about $30 \mathrm{~cm}$ through post-depositional movement but that mixing of discrete occupational surfaces was probably limited to several centuries at most (Hofman, 1992).

Radiocarbon dating of charred hickory nuts from the Cedar Creek Site produced an age of $6,375 \pm 215 \mathrm{yr}$ BP $(7,235 \pm 223$ cal BP $)$, which is consistent with expectations for the SykesWhite Springs artifacts. How could these Early Holocene artifacts become incorporated into an archaeological deposit that was more than two millennia younger? Fortunately, this problem was easily resolved because these Early Holocene projectile points had been patinated then retrieved and resharpened by later artifact scavengers revealing younger marginal flaking over the patinated flake scars (double patination). Apparently, mid-Holocene individuals must have collected these finished Kirk tools from exposed and weathered archaeological deposits and reused them (unlike the fetish purposes described by Cushing).

Relatively heavy vegetation covers most ground surfaces of the southeastern US, which probably limited most prehistoric scavenging opportunities. As a result, recycling of lithic artifacts is neither widespread nor easily recognized in densely vegetated, depositional environments like the eastern US, but it may have been encouraged by periods of localized surface erosion and reductions in the residential mobility of prehistoric peoples living in areas with poor lithic resources. All of these factors were operating in the case of Mid-Holocene occupations of the Central Duck River Basin. Lithic resources were limited in this region and Mid-Holocene foragers exhibited significant reductions in mobility compared to earlier and later inhabitants (Amick 1987; Amick and Carr 1996). Furthermore, the Mid-Holocene climatic record of the greater Mid-South region reflects drying and increased erosion (Brackenridge, 1984; Delcourt and Delcourt, 2004; Klippel and Parmalee, 1982; Stafford et al., 2000; Styles and Klippel, 1996) which would have exposed Early Holocene archaeological surfaces for MidHolocene scavengers. The procurement of these finished tools probably represented a substantial savings of energy in procurement and manufacture, although this limited evidence suggests that recycling was largely opportunistic in these cases.

A more robust record of recycling of projectile points is documented at McFaddin Beach, a $30 \mathrm{~km}$ stretch of sandy beach on the Texas Gulf coast where artifacts and fossils are being transported to the modern beach from submerged, offshore sources (Stright et al., 1999). Sealevel rose about 50 meters in this location during the Late Pleistocene and Early Holocene (Simms et al., 2007) inundating coastal sites of those ages. Subsequent coastal geomorphology processes deposit materials from these underwater archaeological sites on the contemporary McFaddin Beach. In fact, it contains the richest assemblage of Clovis artifacts in the entire state of Texas. As a consequence of these processes, most of the McFaddin Beach artifacts are heavily abraded and waterworn and have been reclaimed and reworked by later inhabitants revealing the diagnostic double patination of reclamation and recycling. The vast majority of the artifacts from McFaddin Beach are in private collections and Stright et al. (1999) have presented an analysis of the largest sample of these assemblage.

Table 5 summarizes and simplifies that analysis by comparing the evidence of recycling (double patina or what Stright et al.[1999] called "retooling") for the Late Pleistocene/Early Holocene versus the Mid-Holocene/Late Holocene. Although the proportion of recycled artifacts in the Late Pleistocene/Early Holocene sample $(8.24 \%, \mathrm{n}=14 / 170)$ is almost three times that 
found in the Mid-Holocene/Late Holocene sample (3.40\%, $n=7 / 206)$, this difference is not statistically significant at the $95 \%$ confidence level. Regardless, this trend conforms to expectations of higher rates of recycling of Late Pleistocene/Early Holocene tools because of the potentially greater time scale of exposure to surface artifact scavengers. Like the Black Rock Desert pluvial lakeshore situation described above, lithic resources are very distant from McFaddin Beach which would have encouraged scavenging of local archaeological remains to meet immediate toolkit needs. The potential for recycling on the active coastal deposits of McFaddin Beach are much higher in comparison to the limited availability from alluvial terrace deposits along the Duck River. These comparisons of recycling evidence from very different geomorphic environments in the Southeastern US reinforce the critical role that site exposure plays in rates of artifact reclamation.

\section{Discussion and Conclusions}

\subsection{Lithic recycling and utility curve modeling of lithic procurement}

The cases above suggest a few critical factors that increase the likelihood of lithic artifact recycling can be identified. The most important of these factors appear to be lithic resource scarcity and lithic resource value. Scarcity may be a function of the natural geologic environment, overexploitation of resources, or mobility limitations. Resource value can be reflected in prior investment (tools that are already shaped) and quality, which tends to include attributes of package size, material grain, and material durability. Often these factors overlap increasing the opportunities for artifact reclamation.

Lithic reclamation and recycling is a special case of lithic procurement and in my earlier consideration of these issues (Amick, 2007), I advocated the use of utility curves to model the relative costs and benefits of various direct procurement strategies. This heuristic model does not apply as well in cases of indirect procurement for social prestige that involves long-distance trade and exchange networks. All other things being equal in this theoretical framework, direct procurement by quarrying is considered to have the highest costs but to yield the highest returns in the form of usable lithic material. Costs are high for this strategy because it often requires special trips to locations that are out of the way of daily subsistence activities. For example, Gould, 1980, pp. 124) noted that among the aborigines of Western Australia, "the procurement of usable stone for tool making was the most time-consuming and laborious part of the entire stone tool making process." Costs involved in lithic resource procurement include travel to the source location, time and energy involved in extracting and preparing the material for transport, transporting the materials back to camp, and the loss of time that could have been devoted to other survival activities. These considerations have served as the basis for numerous transport models of cost:benefit calculations for prehistoric foragers (Beck et al., 2002; Blumenshine et al., 2008; Close, 1996; Lupo, 2006; Metcalfe and Barlow, 1992; Ugan et al., 2003). However, it has been pointed out that transport costs may be reduced through the use of watercraft when feasible (Leudtke, 1979; Blair, 2010) and that lithic procurement may be "dependent only upon random encounters with stone sources and the amount of available space in the mobile toolkit (Brantingham, 2003, p. 487)." Despite these caveats, utility curves still have value in helping point out the reduced costs of direct procurement by surface collection and the benefits of opportunistic collection and reuse of finished tools such as the Cedar Creek and Midway Valley projectile points. Systematic recycling in cases like Buckboard Mesa and McFaddin Beach tend 
to present relatively low procurement costs with relatively high net returns of usable tools or lithic materials. These utility curve models are not faultless, but they do provide useful understanding of the economic factors encouraging lithic recycling.

\subsection{Temporal perspectives, recycling of material culture, and the Longue Durée}

Most considerations of artifact recycling are focused on specific historical events rather than giving priority to long-term historical structures or the perspective of the Longue Durée. Recycling evidence by its nature involves temporal considerations (Amick 2014). In particular, the interval between original use and recycling is critical to defining the difference between reclamation, reuse, and recycling. Temporal implications are also reflected in the tempo and mode of recycling evidence, in other words, the evidence that recycling focuses on particular materials, artifact types, or material attributes - and increases or decreases in frequency through time. For example, the Buckboard Mesa and Midway Valley cases suggest increased intensity of lithic recycling during the Late Holocene with a particular focus on obsidian. The McFaddin Beach case suggests increased intensity of recycling during the Late Holocene, while the Cedar Creek case suggests increased recycling during the Mid-Holocene. Archaeology should be compelled to attempt to control time in its investigations; that focus is one of the strengths of our discipline and where we are capable of making contributions that other disciplines cannot (Bailey 1983, 2007, 2008; Butzer, 1982; Lucas, 2005, 2012). The study of recycling lends itself to that concern very readily and tells us something useful about changes in human behavior and responses to environmental conditions over time.

\subsection{Search for relevance of archaeology to contemporary problems}

One of the main reasons I have reviewed these long-term trends in waste and recycling is to demonstrate how discussions about the "Paleolithic origins of recycling" probably have very limited relationships with modern systems of recycling. This point is especially worth recognizing because archaeological documentation of recycling has been used by the media to suggest some sort of return to the wise environmental sensibilities of our ancestors and that resource conservation is a natural behavior for humans (Current World Archaeology, 5 October 2012; Flowers, 2012; Mitchelsen, 2012; Science Daily, 20 September 2012). Citing the recent report of lithic recycling at the Upper Paleolithic site of Molí del Salt (Vaquero et al. 2012), the media described these examples of prehistoric recycling as evidence of "sustainable practices with natural resources" and drew connections to the practice and environmental significance of materials recycling today. This is not to say that materials recycling is not a helpful practice for reducing our impact on virgin resources, all evidence suggests that it certainly is (Denison and Ruston, 1997; Hershkowitz, 1998; Steuteville, 1993). While Paleolithic recycling may have had something in common with pre-industrial mending and repairing, it has little connection to the contemporary world of recycling. It is important for archaeologists to make this point if we wish to convey to the public what real resource conservation looks like - it involves reduced consumption, making do, and repairing and reusing to excessive degrees. Alternatively, we should be promoting upcycling and cradle-to-cradle viewpoints rather than the current monopoly of inefficient material downcycling associated with cradle-to-grave manufacture and consumption (Bramston and Maycroft, 2014; Braungart and McDonough, 2002; Leonard, 2010; McDonough and Braungart, 2013). 
We should not allow the public to continue being deluded by the myth of "ecologically noble" ancestors living in a golden past where they were in harmony with nature. Our colleagues in human behavioral ecology have investigated these issues thoroughly and it is clear that conservation is rare in human behavior because humans generally seek to maximize the sustainable yield of their resources and efficiency seems to be the most important variable determining resource procurement and consumption rates (Alvard, 1994, 1998; Borgerhoff Mulder and Coppolillo, 2005, pp. 81-103; Hames 1988, 2007; Krech 1999, 2005; Smith 2001; Smith and Wishnie, 2000). As Lucas (2002, p. 13) puts it, "care must be taken not to mythicize an eco-friendly past against a rapacious, consumerist, throwaway present." In fact, our behavior may not be so different from our ancestors in the desire for comfort, convenience, and maximizing the efficiency of resource returns from our work effort.

Another reason I have chosen to explore the relationship of ancient recycling with contemporary recycling is because of an interest in making archaeology relevant to modern problems. This concern is not a new one, it was expressed at least 40 years ago (e.g., Deetz, 1970; Ford, 1973; Fritz, 1973) and has risen to prominence again (Little and Zimmerman, 2010; Sabloff, 2008; Stottman, 2011). In particular, it appears that our long desire to join our cultural anthropology colleagues at their "high table" may have been misplaced (Boyer, 2011; Lyman, 2007; Schiffer, 2011). An area of interdisciplinary scholarship where we may find good articulation is with environmental sciences and human ecology, especially concerning the issues of consumerism and sustainability (Camp et al., 2011; Guttman-Bond, 2010; Majewski and Schiffer, 2001; Rathje 2001; Rathje et al., 2004; Rogers, 2004; Smith, 2010). In addition, the adoption of "time perspective thinking" recommended by Bailey $(2007,2008)$ results in an imperative to connect the past with the present. Failure to do so is one of the reasons that archaeologists like Michael Smith (2010) must ask, "Just how useful is archaeology for scientists and scholars in other disciplines?"

\subsection{Conclusions}

This review shows how recycling activities have changed since the Paleolithic as they have become complicated by capitalist industrial economies even in the Third World where scavengers reclaim discarded materials for materials brokers. Recycling behaviors in developed industrialized countries have become waste disposal practices which are encouraged by politicians at the pressure of citizens wishing to offset guilt from overconsumption caused by the ever growing discard rates associated with mass consumerism. Industry has remained indifferent at best to these trends and frequently has been at odds with the public insistence in support of materials recycling. When the public can be convinced to conduct this waste sorting within their own households, it saves cost and effort for business and government services. In effect, recycling today represents yet another way in which the environmental movement has been coopted by corporate interests. The environmental impacts of material consumption are generally ranked as disposal, followed by recycling, repair, reuse/repurchasing/repurposing, and finally reducing consumption as the most important behavior. Recycling can help reduce the amount of toxic materials reaching our landfills and it can minimize the impacts of increasing rates of consumption and disposal, but it is still not a very effective resource conservation strategy. Nonetheless, it has some potential to increase the efficiency of consumption by reducing the exploitation of virgin resources and reducing the energy expenditure for materials procurement, transport, and manufacture (at the cost of energy expenditure for recyclable procurement, 
transport and remanufacture). Under most current manufacturing methods, it remains more costeffective for industry to mine virgin materials and make new products instead of dealing with the added costs of handling used materials for recycling. Throughout the history of material culture, recycling tends to increase whenever materials become inaccessible or too costly, which is reflected in its relatively low rank as a conservation method by environmental economists (below repairing, reusing, and reducing consumption of objects). This pattern is being witnessed in modern material culture and can be observed in the archaeological record of the near and distant past.

Looking at recycling behavior from the perspective of deep time and diverse materials and social organizations suggests that lithic artifact recycling is certainly not unique. The historical shift from stone to metal technology was facilitated by a number of factors including the greater capacity for recycling in metal technology. Lithic technology is entirely subtractive as tools and by-products become smaller during the manufacturing process, meaning that the recycling potential of lithic artifacts is very limited compared to other materials. Rather than primarily looking at recycling behavior as a form of disturbance to the archaeological assemblages, it can be viewed as the archaeological record of material reclamation and reuse. As such, it can reveal decisions that were made about what to reclaim or rejuvenate, when and where to do it, and how to do it. In this framework, recycling is best viewed as the economy of human time and effort rather than a moral and ethical choice as it is usually framed today (Hawkins, 2006; MacBride, 2011). Unfortunately, the news media tends to frame our prehistoric examples of recycling in these same moral terms implying a sort of innate nobility and harmony with nature among prehistoric peoples who were engaged in recycling. But as we know through the empirical studies of human behavioral ecologists, prehistoric peoples are not anymore noble in their behavior than modern peoples. Such notions of original purity and ecological nobility are as much a myth as the notion of a Golden Age.

While recycling may have its origins in the Paleolithic, it was a very different sort of behavior in which materials were used to exhaustion before discard. The modern system of recycling is very different because it is largely designed to assuage consumer guilt, and it stops short of any real solutions to the overconsumption of resources such as reducing consumption, or systematically reusing and repairing materials - an economy that largely died a century ago and today lives only in isolated pockets among the poorest $2 \%$ of the people on the planet. Reviewing the long history of recycling points out just how much our world has changed in the past century. Recycling is also dependent on changes in technologies and their associated materials and this temporality affects the potential size of the chronological gaps in reclamation and recycling activities. For lithic technology, these gaps could be expected to be much greater than for subsequent materials such as glass and metal. Likewise, the rapid pace of technological change in the industrial age limits the accessibility and utility of material recycling today. In many cases, materials that were used only a few decades ago are not suitable for today's needs or for remanufacturing using today's technology. This recognition could be a sobering thought for those dreaming of the potential to mine our landfills for usable materials. The rubbish of yesterday may have very limited value and utility for recycling tomorrow.

By examining recycling activities throughout history and today, there are several patterns worth noting in developing archaeological expectations. First, recycling is a means of reclaiming and extending the lifespan of objects and utility curves illustrate the energetic advantages of recycling lithic artifacts to reduce the costs of procurement, transport, and handling (manufacture), particularly in the case of tools which still possess significant use-life 
potential. Above all, convenience appears to be a fairly universal factor in materials recycling. As a result, it is most likely that recycling will occur when materials are expensive or valuable in terms of rarity, difficulty of procurement or manufacture, and are still useful. For chipped-stone tool making, it is important that materials have the qualities of absolute size, suitable angular shapes (facilitating flaking platform creation), and the mechanical properties of homogeneity, density, elasticity, fine-grain, hardness, and resiliency (Buck et al., 1994, pp. 20-21; Goodman, 1944; Greiser and Sheets, 1978). Secondly, it is important that the materials are available (e.g., Andrefsky, 1994), which could be better described by the variables of abundance (absolute frequency of usable clasts), ubiquity (dispersion without clustering), and accessibility (lowest procurement effort required). These characteristics could be used to develop relative ranking of lithic resources under different situations, including archaeological deposits of lithic artifacts available for scavenging. In those cases, it is expected that large artifacts made from desirable materials would be preferred, especially those with considerable transport and manufacturing investment (such as refined bifacial tools). This expectation was met in the case of obsidian reclamation preferences in the southern Great Basin and bifacial projectile point recycling at McFaddin Beach and Cedar Creek.

Finally, the roles of environment and mobility come into play when considering recycling. Obviously environments with eroded or stable surfaces offer the greatest potential access for scavenging from archaeological deposits because they will be more likely found on the surface. In this examination, I described cases from the extreme deserts of the southern Great Basin (Midway Valley and Buckboard Mesa), coastal beaches (McFaddin Beach), and erosive climatic episodes (Cedar Creek). Access to materials is enhanced at quarries (like Midway Valley and Buckboard Mesa) and when there is redundancy in land use patterns or frequent reoccupation (such as McFaddin Beach). Thus mobility patterns can play a role in encouraging recycling if routed foraging or repeated reoccupation is common to a settlement system. Low rates of mobility can encourage recycling because they might limit the ability to travel to raw material source areas. As a result, settled villagers might be expected to have exhaustive patterns of material consumption and high rates of recycling. Likewise, high rates of mobility can have similar effects in limiting access to raw material source areas and cause exhaustive use of tools and cannibalization of the toolkit. As I have noted before (Amick, 2007, 2014), the multifactorial complexities of reclamation and recycling decision-making and its environmental and situational circumstances can make the interpretation of recycling evidence very difficult for the archaeologist. Consequently, we need to examine multiple lines of evidence and interpret the recycling behaviors in the context of as much other related evidence as possible. If artifact scavenging or recycling does not conform to these expectations, then other largely opportunistic factors may have come into play (as perhaps in the Cedar Creek and Durbin Site examples) or technological structure and mobility patterns may have altered opportunities for reclaiming materials from the archaeological record. In addition, the mechanical properties of the archaeological materials may not be considered to be suitable for meeting the needs of the technology of the scavengers (much like many older materials are not considered useful for recycling today). Despite these complexities, the evidence of artifact recycling has the potential to tell us much more than that the archaeological record has been degraded. We should expect that recycling of material culture has occurred in the past as a routine part of human behavior just as it continues to do today.

\section{Acknowledgments}


Thanks to Ran Barkai, Cristina Lemorini, and Manuel Vaquero for organizing the workshop leading to this publication and for inviting my participation through support of the Israel Science Foundation and the Wenner-Gren Foundation. This paper has benefited from the thoughtful contributions and conversations of all the participants as well as the reviewers of this paper and my colleagues in the Institute of Environmental Sustainability at Loyola University Chicago (LUC). The College of Arts \& Sciences at LUC helped provide supplemental travel support. Many of the archaeological materials reported in this study resulted from compliance data recovery projects funded by the US Department of Energy (DOE) and the Tennessee Valley Authority (TVA). Walter Klippel at the University of Tennessee served as principal investigator for the TVA contracts while Lonnie Pippin and Dave Rhode at the Desert Research Institute served as principal investigators on the DOE contracts and supported the obsidian hydration analyses used here. Sue Ann Monteleone provided the artifact drawings for Buckboard Mesa and Sarah Moore and Steve Wallmann provided the drawings for the Ernie Durban Site artifacts. Thanks also to the Northeastern Nevada Museum for providing access to the Durbin Collection of Great Basin crescents and Black Rock Concave Base Points. Funding awarded by the Faculty Scholar Program at LUC partially supported the artifact illustrations. I also want to thank my wife and parents for their years of unwavering support of my academic endeavors, it is not easy to put up with a researcher and teacher in the family and I appreciate their many kindnesses. In the end, I remain responsible for this work regardless of all the generous assistance I have enjoyed from so many unselfish friends, students, and colleagues.

\section{References}

Abad, R., 1991. Squatting and scavenging in Smokey Mountain. Philippine Studies 39, 267-285.

Adama, O., 2012. Urban livelihoods and social networks: emerging relations in informal recycling in Kaduna, Nigeria. Urban Forum 23(4) 449-466.

Adams, W.H., 2002a. Machine cut nails and wire nails: American production and use for dating 19th-century and early-20th-century sites. Historical Archaeology 36(4), 66-88.

Adams, W.H., 2002b. Recycling bottles as building materials in the Pacific Islands. Historical Archaeology 36(2), 50-57.

Adeyemi A.S., Olorunnfemi J.F., Adewoye T.O., 2001. Waste scavenging in third world cities: a case study in Ilorin, Nigeria. The Environmentalist 21(2), 93-96.

Afon, A., 2012. A survey of operational characteristics, socioeconomic and health effects of scavenging activity in Lagos, Nigeria. Waste Management and Research 30(7), 664-671.

Almeida, F., 2008. Big puzzles, short stories: advantages of refitting for micro-scale spatial analysis of lithic scatters from Gravettian occupations in Portuguese Extremadura. In: Aubry, T., Almeida, F., Araújo, A.C., Tiffagom, M. (Eds.), Which Diachronies, Which Synchronies, Which Scales? BAR International Series 1831, Oxford, pp. 69-79. 
Alter, H., 1991. The future course of solid waste management in the U.S. Waste Management and Research 9(1), 3-20.

Alvard M., 1994. Conservation by native peoples: prey choice in a depleted habitat. Human Nature 5(2), 127-154.

Alvard M., 1998. Evolutionary ecology and resource conservation. Evolutionary Anthropology $7(2), 62-74$.

Amick, D.S., 1985. Buried Late Holocene terrace site testing in the Central Duck River Basin. In Whyte, T., Boyd, C., Riggs, B. (Eds.), Exploring Tennessee Prehistory. Report of Investigations No. 42. Department of Anthropology, University of Tennessee, pp. 23-38.

Amick, D.S., 1987. Lithic Raw Material Interassemblage Variability in the Central Duck River Basin: Reflections of Middle and Late Archaic Organizational Strategies. Report of Investigations No. 46. Department of Anthropology, University of Tennessee, Knoxville.

Amick, D.S., 2007. Behavioral causes and archaeological effects of lithic artifact recycling. In: McPherron, S.P. (Ed.), Tools versus Cores: Alternative Approaches to Stone Tool Analysis. Cambridge Scholars Publications, Newcastle, pp. 223-252.

Amick, D.S., 2014. Reflection on the origins of recycling: a paleolithic perspective. Lithic Technology 39(1), 64-69.

Amick, D.S., Henton, G.H., Pippin, L.C., 1991. Archaeological Investigations on the Buckboard Mesa Road Project. Technical Report No. 69. Quaternary Sciences Center, Desert Research Institute, Reno.

Andrefsky, W., 1994. Raw-material availability and the organization of technology. American Antiquity, 59(1), 21-34.

Ascher, R., 1968. Time's arrow and the archeology of a contemporary community. In: Chang, K.C. (Ed.), Settlement Archaeology. National Press Books, Palo Alto, pp. 43-52.

Asmin, M., Batool, S., Chaudhry, M. 2012. Scavengers and their role in the recycling of waste in Southwestern Lahore. Resources, Conservation and Recycling 58(1), 152-162.

Bailey, G.N., 1983. Concepts of time in Quaternary prehistory. Annual Review of Anthropology 12, 165-192.

Bailey, G.N., 2007. Time perspectives, palimpsests, and the archaeological record. Journal of Anthropological Archaeology 26, 198-23.

Bailey, G.N., 2008. Time perspectivism, origins and consequences. In: Holdaway, S., Wandsnider, L.A. (Eds.), Time in Archaeology: Time Perspectivism Revisited. University of Utah Press, Salt Lake City, pp. 13-30.

Barkai, R., Lemorini, C., Shimelmitz, R., Lev, Z., Stiner, M.C., Gopher, A., 2009. A blade for all seasons? Making and using Amudian blades at Qesem Cave, Israel. Human Evolution 24(1), $57-75$. 
Barkai, R., Lemorini, C., Gopher, A., 2010. Palaeolithic cutlery 400 000-200 000 years ago: tiny meat-cutting tools from Qesem Cave, Israel. Antiquity 84(325).

Batcho, D.G., 1984. Obsidian Hydration Studies at the Grants Prison Site: Dating the San Jose Complex. Report No. 590. Cultural Resources Management Division, New Mexico State University, Las Cruces.

Beck, C., Taylor, A.K., Jones, G.T., Fadem, C.M., Cook, C.R., Millward, S.A., 2002. Rocks are heavy: transport costs and Paleoarchaic quarry behavior in the Great Basin. Journal of Anthropological Archaeology 21(4), 481-507.

Best, H., Mayerl, J., 2013. Values, beliefs, attitudes: an empirical study on the structure of environmental concern and recycling participation. Social Science Quarterly, 94(3), 691-714.

Binion,E., Gutberlet, J., 2012. The effects of handling solid waste on the wellbeing of informal and organized recyclers: a review of the literature. International Journal of Occupational and Environmental Health 18(1), 43-52.

Blair, S.E., 2010. Missing the boat in lithic procurement: watercraft and the bulk procurement of tool-stone on the Maritime peninsula. Journal of Anthropological Archaeology 29(1), 33-46.

Blengini, G.A., 2009. Life cycle of buildings, demolition and recycling potential: a case study in Turin, Italy. Building and Environment 44(2), 319-330.

Blumenschine, R.J., Masao, F.T., Tactikos, J.C., Ebert, J.I., 2008. Effects of distance from stone source on landscape-scale variation in Oldowan artifact assemblages in the Paleo-Olduvai Basin, Tanzania. Journal of Archaeological Science 35(1), 76-86.

Borgerhoff Mulder, M., Coppolillo, P., 2005. Conservation: Ecology, Economics, and Culture. Princeton University Press, Princeton.

Bourgarit, D., Thomas, N., 2012. Late medieval copper alloying practices: a view from a Parisian workshop of the 14th century AD. Journal of Archaeological Science 39(10), 3052-3070.

Boyer, P., 2011. From studious irrelevancy to consilient knowledge: modes of scholarship and cultural anthropology. In: Slingerland, E., Collard, M. (Eds.), Creating Consilience: Integrating the Sciences and the Humanities. Oxford University Press, New York, pp. 113-129.

Brackenridge, G.R., 1984. Alluvial stratigraphy and radiocarbon dating along the Duck River, Tennessee: implications regarding floodplain origin. Geological Society of American Bulletin 95, 9-25.

Bradley, R., 1988. Hoarding, recycling and the consumption of prehistoric metalwork: technological change in Western Europe. World Archaeology 20(2), 249-260.

Bramston, D., Maycroft, N., 2014. Designing from waste. In: Karana, E., Pedgley, O., Rognoli, V. (Eds.), Materials Experience: Fundamentals of Materials and Design. Elsevier, Amsterdam, in press. 
Brantingham, P.J., 2003. A neutral model of stone raw material procurement. American Antiquity 68(3), 487-509.

Braungart, M., McDonough, W., 2002. Cradle to Cradle: Remaking the Way We Make Things. North Point Press, New York.

Bray, P.J., Pollard, A.M., Carver, M., 2012. A new interpretative approach to the chemistry of copper-alloy objects: source, recycling and technology. Antiquity 86(333), 853-867.

Bridgewater, A., 1985. Refuse composition projections and recycling technology. Resources and Conservation 12, 159-174.

Briggs, L.C., Hencken, H., 1963. Archaeological Investigations near Tipasa, Algeria. American School of Prehistoric Research, Bulletin No. 21. Peabody Museum, Harvard University.

Buck, P.E. , Amick, D.S., Hartwell, W.T., 1994. The Midway Valley Site (26Ny4759): A Prehistoric Lithic Quarry near Yucca Mountain, Nye County, Nevada. Topics in Yucca Mountain Archaeology No. 1. Quaternary Sciences Center, Desert Research Institute, Las Vegas.

Bugoi, R., Poll, I., Mănucu-Adameşteanu, G., Neelmeijer, C., Eder, F., 2013. Investigations of Byzantine glass bracelets from Nufăru, Romania using external PIXE-PIGE methods. Journal of Archaeological Science 40(7), 2881-2891.

Busch, J., 1987. Second time around: a look at bottle reuse. Historical Archaeology 21(1), 67-80.

Butzer, K.W., 1982. Archaeology as Human Ecology. Cambridge University Press, Cambridge.

Cameron, C.M., 1990. Pit structure abandonment in the four corners region of the American Southwest: Late Basketmaker III and Pueblo I Periods. Journal of Field Archaeology 17(1), 27-37.

Cameron, C.M., 1991. Structure abandonment in villages. In: Schiffer, M.B. (Ed.), Archaeological Method and Theory, Vol. 3. Academic Press, New York, pp. 155-194.

Camilli, E.L., 1988. Lithic raw material selection and use in the desert basins of south-central New Mexico. The Kiva 53:147-163.

Camilli, E.L., Ebert, J.I., 1992. Artifact reuse and recycling in continuous surface distributions and implications for interpreting land use patterns. In: Rossignol, J., Wandsnider, L. (Eds.), Time, Space, and Archaeological Landscapes. Plenum Press, New York, pp. 113-136.

Camp, S.L., et al., 2011. Cultivating sustainability through anthropology: University of Idaho's Campus Trash Project. Anthropology News 52(4), 11.

Chang, C., 1988. Nauyalik Fish Camp: an ethnoarchaeological study of activity area formation. American Antiquity 53(1), 145-157. 
Chang, C., 1991. Refuse Disposal at an Inupiat Fish Camp: Ethnoarchaeological Implications of Site Formation Processes. In Staski, E., Sutro, L.D. (Eds.), The Ethnoarchaeology of Refuse Disposal. Anthropological Research Papers No. 42. Arizona State University, Tempe, pp. 53-62.

Chapman, J.J., 1985. Archaeology and the Archaic Period in the southern Ridge-and-Valley Province. In: Dickens, R.S., Ward, H.T. (Eds.), Structure and Process in Southeastern Archaeology. University of Alabama Press, Tuscaloosa, pp. 137-153.

Chapple, R.M., 2007. Late prehistoric recycling at Ballyboley, County Antrim. Ulster Journal of Archaeology 66, 1-5.

Chavaillon, J., Berthelet, A., 2004. The archaeological sites of Melka Kunture. In Chavaillon, J., Piperno, M. (Eds.), Studies on the Early Paleolithic Site of Melka Kunture, Ethiopia. Istituto Italiano di Preistoria e Protostoria, Florence, pp. 25-80.

Close, A.E., 1996. Carry that weight: The use and transportation of stone tools. Current Anthropology 37(3), 545-553.

Corchón, M.S., 1993. El Magdaleniense con triángulos de Las Caldas (Asturias, España). Nuevos datos para la definición del Magdalenense inferior cantábrico. Zephyrus 46, 77-94.

Cooper, T., 2005. Slower consumption reflections on product life spans and the "throwaway society." Journal of Industrial Ecology 9(1/2), 51-67.

Cooper, T., 2008. Challenging the 'refuse revolution': war, waste and the rediscovery of recycling, 1900-50. Historical Research 81(214), 710-731.

Cross, J.C., 1997. Entrepreneurship \& exploitation: measuring independence and dependence in the informal economy. The International Journal of Sociology and Social Policy 17(3/4), 37-62.

Current World Archaeology, October 5, 2012, "Recycling in the Paleolithic." http://www.worldarchaeology.com/news/recycling-in-the-palaeolithic/. Last accessed on Sept. 15, 2013.

Cushing, F.H., 1883. Zuñi Fetiches. Second Annual Report of the Bureau of Ethnology, Smithsonian Institution, Washington, pp. 3-45.

David, A., 2013. Israel conference: cavemen discovered recycling. Associated Press, October 11, 2013. http://bigstory.ap.org/article/israel-conference-cavemen-discovered-recycling

Davies, M., 2008. A childish culture?: Shared understandings, agency and intervention: an anthropological study of street children in northwest Kenya. Childhood 15(3), 309-330.

Deal, M., Hagstrum, M.B., 1995. Ceramic reuse behavior among the Maya and Wanka: implications for archaeology. In: Skibo, J.M., Walker, W.H., Nielsen, A.E. (Eds.), Expanding Archaeology. University of Utah Press, Salt Lake City, pp. 111-125.

Dean J.S., 1978. Independent dating in archaeological analysis. In: Schiffer M.B. (Ed.), Advances in Archaeological Method and Theory, Vol. 1. Academic Press, NY, pp. 223-255. 
Dean, R.B. , 1995. Environmental fads and fallacies. Waste Management and Research 13(3), 201-206.

Debenath, A., 1992. The Place of the Mousterian of the Charente in the Middle Paleolithic of Southwest France. In: Dibble, H.L., Mellars, P. (Eds.), The Middle Paleolithic: Adaptation, Behavior and Variability. The University Museum, University of Pennsylvania, Philadelphia, pp. 53-57.

DeBoer, W.R., Lathrap, D.W., 1979. Making and breaking Shipibo-Conibo ceramics. In: Kramer, C., Ethnoarchaeology: Implications of Ethnography for Archaeology. Columbia University Press, New York, pp. 102-138.

Deetz, J.F., 1970. 1970 Archaeology as a social science. In: Current Directions in Archaeology, Bulletin of the American Anthropological Association 3(3), pt. 2, 115-125.

Degryse, P., Schneider, J., Haack, U., Lauwers, V., Poblome, J., Waelkens, M., Muchez, P., 2006. Evidence for glass 'recycling' using $\mathrm{Pb}$ and $\mathrm{Sr}$ isotopic ratios and $\mathrm{Sr}$-mixing lines: the case of early Byzantine Sagalassos. Journal of Archaeological Science 33(4), 494-501.

Delcourt, P.A., Delcourt, H.R., 2004. Prehistoric Native Americans and Ecological Change: Human Ecosystems in Eastern North America Since the Pleistocene. Cambridge University Press, Cambridge.

Denison, R.A., 1996. Environmental life-cycle comparisons of recycling, landfilling, and incineration: a review of recent studies. Annual Review of Energy and the Environment 21(1), 191-237.

Denison, R.A., Ruston, J.F., 1997. Recycling is Not Garbage. MIT Technology Review 100(7), $55-60$.

Derksen, L., Gartrell, J., 1993. The social context of recycling. American Sociological Review 58(3), 434-442.

De Ryck, I., Adrianens, A. Adams, F., 2005. An overview of Mesopotamian bronze metallurgy during the $3^{\text {rd }}$ millennium BC. Journal of Cultural Heritage 6(3), 261-268.

Diehl, M.W., 1998. The interpretation of archaeological floor assemblages: a case study from the American Southwest. American Antiquity 63(4), 617-634.

Drackner, M. 2005. What is waste? To whom? - An anthropological perspective on garbage. Waste Management and Research 23(3):175-181.

Drechou, H., Hivernel, F., Karpoff, R., 1968. Nouvelles stations préhistoriques dans les reliefs anciens de l'Arabie Saoudite: industries paléolithique et néolithique murets et gravures rupestres. Bulletin de la Société Préhistorique Française, 65(3), 817-832.

Dupree, L., 1965. Archaeological reconnaissance in Southern Tripolitania and Northern Fezzan, Libya. Man 65 (Sept-Oct), 147-149. 
Durning, A.T., 1996. This Place on Earth: Home and the Practice of Permanence. Sasquatch Books, Seattle.

Earls, A., Lintz, C.R., Trierweiler, W.N., 1989. Chronology. In Bertram, J.B., et al. (Eds.), Report of Surface Collection and Testing at 18 Sites Near Abiquiu Reservoir, Northern New Mexico, Mariah Associates, Inc., Albuquerque, 305-357.

Eckelman, M.J., Chertow, M.R., 2009. Quantifying life cycle environmental benefits from the reuse of industrial materials in Pennsylvania. Environmental Science and Technology 43(7), $2550-2556$.

Ekshtain, R., Barzilai, O., Inbar, M., Milevski, I., Ullman, M., 2012. Givat Rabi East, a new Middle Paleolithic knapping site in the Lower Galilee (Israel). Paléorient 37(2), 107-122.

Fagnart, J.-P., 1991. New observations on the Late Upper Palaeolithic site of Belloy-sur-Somme (Somme, France). In Barton, N., Roberts, A.J., Roe, D.A. (Eds.), The Late Glacial in North-West Europe: Human Adaptation and Environmental Change at the End of the Pleistocene. C.B.A. Research Report No 77. Council of British Archaeology, York, pp. 213-227.

Faulkner, C.H., 2004. Moved buildings: a hidden factor in the archaeology of the built environment. Historical Archaeology 38(2), 55-67.

Feeny, D., Berkes, F., McCay, B.J., Acheson, J.M., 1990. The tragedy of the commons: twentytwo years later. Human Ecology 18(1), 1-19.

Figueiredo, E., Silva, R., Senna-Martinez, J., Araújo, F., Braz Fernandes, F., Inês Vaz, J., 2010. Smelting and recycling evidences from the Late Bronze Age habitat site of Baiões (Viseu, Portugal). Journal of Archaeological Science 37(7), 1623-1634.

Fleming, R., 2012. Recycling in Britain after the fall of Rome's metal economy. Past and Present 217(1), 3-45.

Flowers, A., 2012 "Research says history of recycling dates to our Paleolithic ancestors." redOrbit.com Science News, http://www.redorbit.com/news/science/1112698610/history-ofrecycling-dates-to-paleolithic-092112/. Last accessed on Sept 15, 2013.

Fontana, V., 1998. Procedures to analyze intra-site pottery distribution, applied to the Neolithic site of Fimon, Molino Casarotto (Italy), Housesite No. 3. Journal of Archaeological Science 25(11), 1067-1072.

Ford, R.I., 1973. Archeology serving humanity. In: Redman, C.L. (Ed.), Research and Theory in Current Archeology. John Wiley \& Sons, New York, pp. 59-82.

Foster, H.E., Jackson, C.M., 2010. The composition of late Romano-British colourless vessel glass: glass production and consumption. Journal of Archaeological Science 37(12), 3068-3080.

Fritz, J.M., 1973. Relevance, archeology, and subsistence theory. In: Redman, C.L. (Ed.), Research and Theory in Current Archeology. John Wiley \& Sons, New York, pp. 59-82. 
Galili, E., Weinstein-Evron, M., 1985. Prehistory and Paleoenvironments of Submerged Sites along the Carmel Coast of Israel. Paléorient 11(1), 37-52.

Goodman, M.E., 1944. The physical properties of stone tool materials. American Antiquity 9, 415-433.

Gopher, A., Barkai, R., Shimelmitz, R., Khalaily, M. Lemorini, C., Hershkovitz, I., Stiner, M., 2005. Qesem Cave: an Amudian site in central Israel. Journal of the Israel Prehistoric Society 35, 69-92.

Goren-Inbar, N., 1985. The lithic assemblage of Berekhatram Acheulian site, Golan Heights. Paléorient 11(1), 7-28.

Gould, R.A., 1980. Living Archaeology. Cambridge University Press, New York.

Gould, R.A., Koster, D.A., Sontz, A.H. 1971. The lithic assemblage of the Western Desert Aborigines of Australia. American Antiquity 36:149-169.

Gowan, T., 1997. American untouchables: homeless scavengers in San Francisco's underground economy. The International Journal of Sociology and Social Policy 17(3/4), 159-190.

Gresier, S.T., Sheets, P.D., 1978. Raw material as a functional variable in use-wear studies. In: Hayden, B. (Ed.), Lithic Use-Wear Analysis. Academic Press, New York, pp. 289-296.

Grogan, P.L., 1996. Product repair gives way to recycling. BioCycle 37(11), 86.

Grossman, E., 2006. High Tech Trash: Digital Devices, Hidden Toxics, and Human Health. Island Press, Washington.

Grothues, J., 1988. Aladins Neue Lampe: Recycling in der Dritten Welt. Trickster, Munich.

Gunn, S.E., Ostos, Z., 1992. Dilemmas in tackling child labour: the case of scavenger children in the Philippines. International Labour Review 131, 629-646.

Guttmann-Bond, E., 2010. Sustainability out of the past: how archaeology can save the planet. World Archaeology 42(3), 355-366.

Hames R., 1988. Game conservation or efficient hunting. In: McCay, B., Acheson, J. (Eds.), Capturing the Commons: Anthropological Approaches to Resource Management. University of Arizona Press, Tucson, pp. 192-207.

Hames, R., 2007. The ecologically noble savage debate. Annual Review of Anthropology 36, 177-190.

Hardin, G., 1968. The tragedy of the commons. Science 162, 1243-1248.

Harrison, R.J., Moreno López, G., Legge, A.J., 1994. Moncí; Un Poblado de la Edad del Bronce ( Borja, Zargoza). Collección Arqueología 16, Disputací General de Zaragoza, Zaragoza. 
Hawkins, G., 2006. The Ethics of Waste: How We Relate to Rubbish. Rowman \& Littlefield, Lanham, MD.

Hayami, Y., Dikshit, A.K., Mishra, S.N., 2006. Waste pickers and collectors in Delhi: poverty and environment in an urban informal sector. Journal of Development Studies 42(1), 41-69.

Hayden, B., Cannon, A., 1983. Where the garbage goes: refuse disposal in the Maya Highlands. Journal of Anthropological Archaeology 2(2):117-163.

Hershkowitz, A., 1998. In Defense of Recycling. Social Research 65(1), 141-218.

Hildebrand, J.A., 1978. Pathways revisited: a quantitative model of discard. American Antiquity 43(2), 274-279.

Hofman, J.L., 1992. Defining buried occupation surfaces in terrace sediments. In: Hofman, J.L., Enloe, J.G. (Eds.), Piecing Together the Past: Applications of Refitting Studies in Archaeology. BAR International Series 578, British Archaeological Reports, Oxford, pp. 128-150.

Hole, F., 1959. A reanalysis of basal Tabbat al-Hammam, Syria. Syria 36(3/4), 149-183.

Horne, L. 1983. Recycling in an Iranian village: ethnoarchaeology in Baghestan. Archaeology 35(4), 16-21.

Horne, L. 1991. Reading village plans: architecture and social change in northeastern Iran. Expedition 33(1), 44-52.

Hornik, J., Cherian, J., Madansky, M., Narayana, C., 1995. Determinants of recycling behavior: a synthesis of research results. The Journal of Socio-Economics 24(1), 105-127.

Hovers, E., Buller, A., Ekshtain, R., Oroni, M., Yeshurun, R., 2008. Ein Qashish - A New Middle Paleolithic Open-Air Site in Northern Israel. Journal of the Israel Prehistoric Society 38 $7-40$.

Humes, E., 2012. Garbology: Our Dirty Love Affair with Trash. Avery, New York.

Hunt, C., 1996. Child waste pickers in India: the occupation and its health risks. Environment and Urbanization 8(2), 111-118.

Huysman, M., 1994. Waste picking as a survival strategy for women in Indian cities. Environment and Urbanization 6(2), 155-174.

Iovita, R., Fitzsimmons, K.E., Dobos, A., Hambach, U., Hilgers, A., Zander, A., 2012. Dealul Guran: evidence for Lower Palaeolithic (MIS 11) occupation of the Lower Danube loess steppe. Antiquity 86, 973-989.

Isaac, G.L., 1977. Olorgesailie: Archeological Studies of a Middle Pleistocene Lake Basin in Kenya. University of Chicago Press, Chicago. 
Jackson, R.J., 1985. Obsidian Hydration Analysis. In Thomas, D.H. (Ed.), The Archaeology of Hidden Cave, Nevada. Anthropological Papers 61(1). American Museum of Natural History, New York, pp. 354-357.

Jelinek, A.J., 2013. Neandertal Lithic Industries at La Quina. University of Arizona Press, Tucson.

Judd, N.M., 1954. The Material Culture of Pueblo Bonito. Smithsonian Miscellaneous Collections 124. Smithsonian Institution, Washington.

Justice, N.D., 2002. Stone Age Spear and Arrow Points of California and the Great Basin. Indiana University Press, Bloomington.

Kaiser, F.G., Ranney, M., Hartig, T., Bowler, P.A., 1999. Ecological behavior, environmental attitude, and feelings of responsibility for the environment. European Psychologist 4(2), 59-74.

Kamp, K., 1991. Waste disposal in a Syrian Village. In Staski, E., Sutro, L.D. (Eds.), The Ethnoarchaeology of Refuse Disposal. Anthropological Research Papers No. 42. Arizona State University, Tempe, pp. 23-31.

Karageorghis, V., Kassianidou, V., 1999. Metalworking and recycling in Late Bronze Age Cyprus - the evidence from Kition. Oxford Journal of Archaeology 18(2), 171-188.

Kaufmann, B., 1984. The Vista Hills Site: Eight Thousand Years at the Edge of the Hueco Bolson. Report No. 563. Cultural Resources Management Division, New Mexico State University, Las Cruces.

Kay, T., 1994. Salvo in Germany: Reiner Pilz. Salvo Monthly 23 (11 October 1994), pp. 11-14.

Kent, S., 1990. A question of inference: interpretations of site abandonment behavior from survey data. Historical Archaeology 24(2), 70-81.

Keyes, W., 1974. Manila Scavengers: The Struggle for Urban Survival. Ateneo de Manila University, Manila.

Kimbugwe, E., Ibitayo, O.O, 2013. Analysis of characteristics, activities, and exposure to vermin of human landfill scavengers in a developing nation. Environment Systems and Decision (online publication), August 2013.

Klippel, W.E., Parmalee, P.W., 1982. Diachronic variation in insectivores from Cheek Bend Cave and environmental change in the Midsouth. Paleobiology 8(4), 447-458.

Krausmann, F., Gingrich, S., Eisenmenger, N., Erb, K.-H., Haberl, H., Fischer-Kowalski, M., 2009. Growth in global materials use, GDP and population during the 20th century. Ecological Economics 68(10), 2696-2705.

Krech, S., 1999. The Ecological Indian: Myth and History. Norton, New York.

Krech, S. 2005. Reflections on conservation, sustainability, and environmentalism in indigenous North America. American Anthropologist 107(1), 78-86. 
Krook, J., Svensson, N., Eklund, M., 2012. Landfill mining: a critical review of two decades of research. Waste Management 32(3), 513-520.

Kuijt, I., Russell, K.W., 1993. Tur Imdai rockshelter, Jordan: debitage analysis and historic Bedouin lithic technology. Journal of Archaeological Science 20(6), 667-680.

Lahiri, N., 1995. Indian metal and metal-related artefacts as cultural signifiers: an ethnographic perspective. World Archaeology 27(1), 116-132.

Leonard, A., 2010. The Story of Stuff: How Our Obsession with Stuff is Trashing the Planet, Our Communities, and Our Health - and a Vision for Change. Free Press, New York.

Le Roux, C.-T., 1984. A propos des fouilles de Gavrinis (Morbihan): nouvelles données sur l'art mégalithique armoricain. Bulletin de la Société Préhistorique Française, 81, 240-245.

Lister, F.C., Lister, R.H., 1981. The recycled pots and potsherds of Spain. Historical Archaeology 15(1), 66-78.

Little, B., Zimmerman, L.J., 2010. In the public interest: creating a more activist, civically engaged archaeology. In: Ashmore, W., Lippert, D., Mills, B. (Eds.), Voices in American Archaeology. Society for American Archaeology Press, Washington, pp. 131-159.

Lucas, G., 2002. Disposability and dispossession in the twentieth century. Journal of Material Culture 7(1), 5-22.

Lucas, G., 2005. The Archaeology of Time. Routledge, New York.

Lucas, G., 2012. Understanding the Archaeological Record. Cambridge University Press, New York.

Luedtke, B E., 1979. Quarrying and quantification: estimates of lithic material demand. Midcontinental Journal of Archaeology 4(2), 255-266.

Lupo, K.D., 2006. What explains the carcass field processing and transport decisions of contemporary hunter-gatherers? Measures of economic anatomy and zooarchaeological skeletal part representation. Journal of Archaeological Method and Theory 13(1), 19-66.

Lyman, R.L., 2007. Archaeology's quest for a seat at the high table of anthropology. Journal of Anthropological Archaeology 26, 133-149.

MacBride, S., 2011. Recycling Reconsidered: The Present Failure and Future Promise of Environmental Action in the United States. MIT Press, Cambridge.

Majewski, T., Schiffer, M.B., 2001. Beyond consumption: toward an archaeology of consumerism. In: Buchli, V., Lucas, G. (Eds.), Archaeologies of the Contemporary Past. Routledge, London, pp. 26-50.

Makkay J., 1992. Excavations at the Körös Culture settlement of Endrõd-Öregszõlõk 119 in 1986-1989. In: Bökönyi, S. (Ed.), Cultural and Landscape Changes in South-east Hungary I. Reports on the Gyomaendrõd Project (Archaeolingua Main Series 1). Budapest, pp. 121-193. 
Martin, A.S., 1993. Makers, buyers, and users: consumerism as a material culture framework. Winterthur Portfolio 28(2/3), 141-157.

Martin, H. 1906. Silex a double patine. Bulletin de la Société Préhistorique de France 3(7), 273-274.

Matos, G., Wagner, L., 1998. Consumption of materials in the United States, 1900-1995. Annual Review of Energy and the Environment 23, 107-122.

McBurney, C.B.M., Hey, R.W., 1955. Prehistory and Pleistocene Geology in Cyrenaican Libya: A Record of Two Seasons' Geological and Archaeological Fieldwork in the Gebel Akhdar Hills, with a Summary of Prehistoric Finds from Neighbouring Territories. Occasional Publications of the Cambridge University Museum of Archaeology and Ethnology No. 4.

McDonough, W., Braungart, M., 2013. The Upcycle: Beyond Sustainability--Designing for Abundance. North Point Press, New York.

McGuire, R.H., 1984. Recycling: great expectations and garbage outcomes. American Behavioral Scientist 28(1), 93-114.

Medina, M., 2007. The World's Scavengers: Salvaging for Sustainable Consumption and Production. AltaMira, Plymouth, UK.

Metcalfe, D., Barlow, K.R., 1992. A model for exploring the optimal trade-off between field processing and transport. American Anthropologist 94(2), 340-356.

Miller, B., 2000. Fat of the Land: Garbage of New York - The Last Two Hundred Years. Basic Books, New York.

Michelsen, T., 2012 "Archaeologists find evidence of prehistoric recycling efforts." Life is Green: A Green Living Lifestyle Blog, http://www.lifeisgreen.com/archaeologists-find-evidenceof-prehistoric-recycling-efforts/2012/09/26/. Last accessed on Sept 15, 2013.

Moreno-Sanchez, R., Maldonado, J., 2006. Surviving from garbage: the role of informal wastepickers in a dynamic model of solid-waste management in developing countries. Environment and Development Economics 11, 371-391.

Motloch, H., 2003. Where Stuff Comes From: How Toasters, Toilets, Cars, Computers and Many Other Things Come to Be As They Are. Routledge, New York.

Needham S.P., Leese M.N., Hook D.R., Hughes M.J., 1989. Developments in the Early Bronze Age metallurgy of Southern Britain. World Archaeology 20(3), 383-402.

Nishiaki, Y., 1985. Truncated-faceted flakes from Levantine Mousterian assemblages. Bulletin No. 4. Department of Archaeology, University of Tokyo, pp. 215-226.

Nodarou, E., Frederick, C., Hein, A., 2008. Another (mud)brick in the wall: scientific analysis of Bronze Age earthen construction materials from East Crete. Journal of Archaeological Science 35(11), 2997-3015. 
O'Brien, M., 2008. A Crisis of Waste? Understanding the Rubbish Society. Routledge, New York.

Ocasiones, L.G., de Lange, M., van Naerssen, T., 2009. Social capital and environmental health in two low-income neighborhoods in Cebu City. Philippine Quarterly of Culture and Society $37(2 / 3), 107-135$.

Orton, C., Hughes, M., 2013. Pottery in Archaeology ( $2^{\text {nd }}$ edition). Cambridge University Press, New York.

Ostrom, E., 1999. Coping with Tragedies of the Commons. Annual Review of Political Science 2, 493-535.

Ottaway, B., Roberts, B., 2008. The emergence of metalworking. In: Jones, A. (Ed.), Prehistoric Europe: Theory and Practice. Blackwell, London, pp. 193-225.

Peckham, S.L., 1980. The Piojo Dunes Site (LA 13669): Archaeological Investigation in Southwestern Sandoval County, New Mexico. Laboratory of Anthropology Note No. 266. Museum of New Mexico, Office of Archaeological Studies, Santa Fe.

Pellow, D.N., 2002. Garbage Wars: The Struggle for Environmental Justice in Chicago. The MIT Press, Cambridge.

Peña, J. T., 2007. Roman Pottery in the Archaeological Record. Cambridge University Press, New York.

Perrot J., 1955. Le Paléolithique supérieur d'El Quseir et de Masaraq an Na'aj (Palestine). Inventaire de la collection René Neuville I et II. Bulletin de la Société Préhistorique de France 52(8), 493-506.

Pettegrew, D.K., 2002. Chasing the Classical farmstead: assessing the formation and signature of rural settlement in Greek landscape archaeology. Journal of Mediterranean Archaeology 14(2), 189-209.

Plunket, P., Uruñuela, G., 2005. Recent research in Puebla prehistory. Journal of Archaeological Research 13(2), 89-127.

Potts, D.T., 2007. Babylonian sources of exotic raw materials. In: Leick, G. (Ed.), The Babylonian World. Routledge, New York, pp. 124-140.

Porraz, G., Texier, P.-J., Archer, W., Piboule, M., Rigaud, J.-P., Tribolo, C., 2013. Technological successions in the Middle Stone Age sequence of Diepkloof Rock Shelter, Western Cape, South Africa. Journal of Archaeological Science 40(9), 3376-3400.

Pozorski, T., Pozorski, S., 2005. Architecture and chronology at the site of Sechín Alto, Casma Valley, Peru. Journal of Field Archaeology 30(2), 143-161.

Pradel, L., 1958. Localisation d'une double patine sur quatre pointes Moustériennes incurvées. Bulletin de la Société Préhistorique de France 55(9), 554-555. 
Quaghebeur, M., Laenen, B., Geysen, D., Nielsen, P., Pontikes, Y., Van Gerven, T., Spooren, J., 2013. Characterization of landfilled materials: screening of the enhanced landfill mining potential. Journal of Cleaner Production (55), 72-83.

Rathje, W.L., 1978. Archaeological ethnography... because sometimes it is better to give than to receive. In: Gould, R.A. (Ed.), Explorations in Ethnoarchaeology. University of New Mexico Press, Albuquerque, pp. 49-75.

Rathje, W.L., 1979. Modern material culture studies. In: Schiffer, M.B. (Ed.), Advances in Archaeological Method and Theory, Academic Press, New York, pp. 1-35.

Rathje, W.L., 1997. The archaeology of us. In: Ciegelski, C. (Ed.), Encyclopaedia Britannica's Yearbook of Science and the Future - 1997. Encyclopaedia Britannica, New York, pp. 158-177.

Rathje, W.L., 2001. Integrated archaeology: a garbage paradigm. In: Buchli, V., Lucas, G. (Eds.), Archaeologies of the Contemporary Past. Routledge, London, pp. 63-76.

Rathje, W.L., Hughes, W.W., Wilson, D.C., Tani, M.K., Archer, G.H., Hunt, R.G., Jones, T.W., 1992. The archaeology of contemporary landfills. American Antiquity 57(3), 437-447.

Rathje, W.L., LaMotta, V.M., Longacre, W.A., 2004. Into the black hole: archaeology 2001 and beyond. In: Cunliffe, B. Davies, W., Hodder, I., Renfrew, C., Snodgrass, A. (Eds.), Archaeology: The Widening Debate. The British Academy, Oxford, pp. 497-539.

Rathje, W.L., Murphy, C. 1992. Rubbish! The Archaeology of Garbage. HarperCollins, New York.

Raymond, A.W., 1985. Evaluating the occupational history of lithic scatters: analysis of obsidian hydration measurements. North American Archaeology 6:115-133.

Redford, K.H., 1991. The ecologically noble savage. Cultural Survival Quarterly 9(1), 41-44.

Reno, J., 2012. Paper and landfills. In: Zimring, C., Rathje, W. (Eds.), Encyclopedia of Consumption and Waste: The Social Science of Garbage. SAGE Publications, Thousand Oaks, CA, pp. 656-659.

Richter, A.M., 2009. Recycling monuments: the Hinduism/Buddhism switch at Angkor. http://archive.cyark.org/recycling-monuments-the-hinduismbuddhism-switch-at-angkor-blog. Last accessed September 15, 2013.

Riley, M., 2008. From salvage to recycling - new agendas or same old rubbish? Area 40(1), 79-89.

Rockson, G.N.K., Kemausuor, F., Seassey, R., Yanful, E., 2013. Activities of scavengers and itinerant buyers in Greater Accra, Ghana. Habitat International 39, 148-155.

Rogers, J.D., 2004. The global environmental crisis: an archaeological agenda for the 21st century. In: Redman, C.L., James, S.R., Fish, P.R., Rogers, J.D. (Eds.), The Archaeology of Global Change: The Impact of Humans on Their Environment. Smithsonian Institution Press, Washington, pp. 271-277. 
Rogers, H., 2005. Gone Tomorrow: The Hidden Life of Garbage. The New Press, New York.

Rollefson, G.O., 1981. The Late Acheulean site at Fjaje, Wadi el-Bustan, Southern Jordan. Paléorient 7(1), 5-21.

Rosen, S.A., 1996. The decline and fall of flint. In: Odell, G.H. (Ed.), Stone Tools: Theoretical Insights into Human Prehistory. Plenum Press, New York, pp. 129-158.

Rosen, S., Gopher, A., 2003. Flint tools from the survey. In: Beit-Arieh, I. (Ed.), Archaeology of Sinai: The Ophir Expedition. Tel Aviv University Archaeological Monograph 21, pp. 184-195.

Ross, L.A., 1985. 16th-century Spanish Basque coopering. Historical Archaeology 19(1), 1-31.

Ross, P., 2013. Second time around B.C. Newsweek, October 17, 2013. http://www.newsweek.com/2013/10/18/second-time-around-bc-243688.html

Sabloff, J., 2008. Archaeology Matters: Action Archaeology in the Modern World. Left Coast Press, Walnut Creek, CA.

Scheinberg, A., Spies, S., Simpson, M.H., Mol, A.P.J., 2011. Assessing urban recycling in lowand middle-income countries: building on modernised mixtures. Habitat International 35(2), 188-198.

Schenck, R., Blaauw, P.F., 2011. The work and lives of street waste pickers in Pretoria-a case study of recycling in South Africa's urban informal economy. Urban Forum 22(4), 411-430

Schiffer, M.B., 1972. Archaeological context and systemic context. American Antiquity 37(2), 156-165.

Schiffer, M.B., 1976. Behavioral Archeology. Academic Press, New York.

Schiffer, M.B., 1986. Radiocarbon dating and the "old wood" problem: the case of the Hohokam chronology. Journal of Archaeological Science 13(1), 13-30.

Schiffer, M.B., 2010. Behavioral Archaeology: Principles and Practice. Equinox, London.

Schiffer, M.B., 2011. Archaeology as anthropology: where did we go wrong? The SAA Archaeological Record 11(4), 22-28.

Schiffer, M.B., Downing, T.E., McCarthy, M., 1981. Waste not, want not: an ethnoarchaeological study of re-use in Tucson, Arizona. In: Gould, R.A., Schiffer, M.B. (Eds.), Modern Material Culture: The Archaeology of Us. Academic Press, New York, pp. 67-86.

Schlanger, S.H., 1991. On manos, metates, and the history of site occupations. American Antiquity 56(3), 460-474.

Schultz, P.W., Oskamp, S., Mainieri, T., 1995. Who recycles and when? A review of personal and situational factors. Journal of Environmental Psychology 15(2), 105-121. 
Science Daily, 20 September 2012, "Humans were already recycling 13,000 years ago, burnt artifacts show." http://www.sciencedaily.com/releases/2012/09/120920082536.htm. Last accessed on Sept 15, 2013.

Shepard, A.O., 1956. Ceramics for the Archaeologist. Publication No. 609. Carnegie Institution of Washington, Washington, DC $\left(5^{\text {th }}\right.$ printing, 1965).

Siegel, P.E., Roe, P.G., 1986. Shipibo archae-ethnography: site formation processes and archaeological interpretation. World Archaeology 18(1), 96-115.

Silvestri, A., 2008. The coloured glass of Iulia Felix. Journal of Archaeological Science 35(6), 1489-1501.

Silvestri, A., Marcante, A., 2011. The glass of Nogara (Verona): a "window" on production technology of mid-Medieval times in Northern Italy. Journal of Archaeological Science 38(10), 2509-2522.

Simmons, S.E., Shugar, A.N., 2008. The context, significance and technology of copper metallurgy at Late Postclassic Spanish Colonial Period Lamanai, Belize. Research Reports in Belizean Archaeology 5, 125-134.

Simms, A., Lambeck, K., Purcell, A., Anderson, J.B., Rodriguez, A.B., 2007. Sea-level history of the Gulf of Mexico since the Last Glacial Maximum with implications for the melting history of the Laurentide Ice Sheet. Quaternary Science Reviews 26(7-8), 920-940.

Simms, S.R., 1983. The effects of grinding stone reuse on the archaeological record in the Eastern Great Basin. Journal of California and Great Basin Anthropology 5(2), 98-102.

Simpson-Herbert, M., Mitrovic, A., Zajic, G., 2005. A Paper Life: Belgrade's Roma in the Underworld of Waste Scavenging and Recycling. Water, Engineering, and Development Center, Loughborough University, Leicestershire.

Smith E.A., Wishnie M., 2000. Conservation and subsistence in small-scale societies. Annual Review of Anthropology 29, 493-524.

Smith, M.E., 2010. Just how useful is archaeology for scientists and scholars in other disciplines? The SAA Archaeological Record 10(4), 15-20.

Smith N., 2001. Are indigenous peoples conservationists? Preliminary results from the Machiguenga of the Peruvian Amazon. Rationality and Society 13(4), 229-261.

Spinapolce, E., Garcea, E., 2013. The Aterian from the Jebel Gharbi (Libya): new technological perspectives from North Africa. African Archaeological Review 30(2), 169-194.

Stanislawski, M.B., 1978. If pots were mortal. In: Gould, R.A. (Ed.), Explorations in Ethnoarchaeology. University of New Mexico Press, Albuquerque, pp. 201-227.

Stafford, C.R., Richards, R.L., Anslinger. C.M., 2000. The bluegrass fauna and changes in Middle Holocene hunter-gatherer foraging in the southern Midwest. American Antiquity 65(2), 317-336. 
Steuteville, R., 1993. Recycling: the price is right. BioCycle 34(9), 54-59.

Stottman, M.J. (Ed.), 2011. Archaeologists As Activists: Can Archaeologists Change the World? University of Alabama Press, Tuscaloosa.

Strasser, S., 1999. Waste and Want: A Social History of Trash. Metropolitan Books, New York.

Stright, M.J., Lear, E.M., Bennett, J.F., 1999. Spatial Data Analysis of Artifacts Redeposited by Coastal Erosion: A Case Study of McFaddin Beach, Texas. OCS Study MMS 99-0068. Prepared for U.S. Department of the Interior, BLM/Minerals Management Service, Herndon, VA.

Stuart, I., 1993. Bottles for jam? An example of recycling from a post-contact archaeological site. Australian Archaeology 36, 17-21.

Styles, B.W., Klippel, W.E., 1996. Mid-Holocene faunal exploitation in the Southeastern United States. In: Sassaman, K.E., Anderson, D.G. (Eds.), Archaeology of the Mid-Holocene Southeast. University of Florida Press, Gainesville, pp. 115-133.

Tadlock, W.L., 1966. Certain crescentic stone objects as a time marker in the western United States. American Antiquity 31(4), 662-675.

Tevera, D.S., 1994. Dump scavenging in Gaborone, Botswana: anachronism or refuge occupation of the poor? Geografiska Annaler, Series B, Human Geography 76(1), 21-32.

Thiéaut, C., Claud, É., Mourre, V., Chacón, M.-G., Asselin, G., Brenet, M., Paravel, B., 2010. The recycling and reuse of cores and bifaces during the Middle Paleolithic in Western Europe: functional and cultural interpretations. Varia section of the online review P@lethnologie. http://www.palethnologie.org. Last accessed on September 15, 2013.

Tomka, S.A., 1993. Site abandonment behavior among transhuman agro-pastoralists: the effects of delayed curation on assemblage composition. In: Cameron, C.M., Tomka, S.A. (Eds.), Abandonment of Settlements and Regions: Ethnoarchaeological and Archaeological Approaches. Cambridge University Press, Cambridge, pp. 11-24.

Toro-Moyano, I., de Lumley, H., Fajardo, B., Barsky, D., Cauche, D., Celiberti, V., Grégoire, S., Martinez-Navarro, B., Espigares, M.P., Ros-Montoya, S., 2009. L'industrie lithique des gisements du Pléistocène inférieur de Barranco León et Fuente Nueva 3 à Orce, Grenade, Espagne. L'Anthropologie 113(1), 111-124.

Tremblay, C., Gutberlet, J., Peredo, A.M., 2010. United We Can: resource recovery, place and social enterprise. Resources, Conservation and Recycling, 54(7), 422-428. Ugan, A., Bright, J., Rogers, A., 2003. When is technology worth the trouble? Journal of Archaeological Science 30(10), 1315-1329.

Underwood, J., 1993. The Bridge People: Daily Life in a Camp of the Homeless. University Press of America, Lanham, MD. 
Van Beukering, P.J.H., Curleed, T.R., 1998. Recycling of materials: local or global? In: Vellinga, P., Gupta, J., Berkhout, F. (Eds.), Managing a Material World. Kluwer Academic Press, Dordrecht, pp. 229-239.

Van Beukering, P.J.H., Bouman, M., 2001. Empirical evidence on recycling and trade of paper and lead in developed and developing countries. World Development 29(10), 1717-1737.

van der Zee, D.J., Achterkamp, M.C., Visser, B.J., 2004. Assessing the market opportunities of landfill mining. Waste Management 24, 795-894.

Vaquero, M., 2008. The history of stones: behavioural inferences and temporal resolution of an archaeological assemblage from the Middle Palaeolithic. Journal of Archaeological Science 35(12), 3178-3185.

Vaquero, M., Alonso, S., García-Catalán, S., García-Hernández, A., Gómez de Soler, B., Rettig, D., Soto, M., 2012. Temporal nature and recycling of Upper Paleolithic artifacts: the burned tools from the Molí del Salt site (Vimbodí i Poblet, northeastern Spain). Journal of Archaeological Science 39(8), 2785-2796.

Vaquero, M., 2011. New perspectives on recycling of lithic resources using refitting and spatial data. Quartär 58, 113-130.

Vergara, S.E., Tchobanoglous, G., 2012. Municipal solid waste and the environment: a global perspective. Annual Review of Environment and Resources 37, 277-309.

Vining, J., Ebreo, A., 1990. What makes a recycler? A comparison of recyclers and nonrecyclers. Environment and Behaviour 22(1), 55-73.

Wee, S.T., 2012. Socioeconomic of scavenger: study case at Johore State, Malaysia. Research on Humanities and Social Sciences 2(7), 91-97.

Wernick, I.K., Themelis, N.J., 1998. Recycling metals for the environment. Annual Review of Energy and the Environment 23, 465-497

Wilk, R., Schiffer, M.B., 1979. The archaeology of vacant lots in Tucson, Arizona. American Antiquity 44(3), 530-536.

Wilson, L., 2007. Understanding prehistoric lithic raw material selection: application of a gravity model. Journal of Archaeological Method and Theory 14(4), 388-411.

Wilson, D.C., 1995. The analysis of domestic reuse in historical archaeology. In: Skibo, J.M., Walker, W.H., Nielsen, A.E. (Eds.), Expanding Archaeology. University of Utah Press, Salt Lake City, pp. 126-140.

Zimring, C.A., 2005. Cash for Your Trash: Scrap Recycling in America. Rutgers University Press, New Brunswick. 
Amick - Paleolithic recycling - figure captions

Fig. 1. North American site locations discussed in the text.

Fig. 2. Weathered and recycled Great Basin Stemmed (Early Holocene) projectile point (Reference \#1428) from Midway Valley, Fortymile Wash. Stem exhibits a more recent flake removed during the recycling effort. Percussion removal of this flake probably caused the artifact to simultaneously break transversely because of bending failure. Proximal and distal fragments can be refit along the surface of this unweathered break.

Fig. 3. Recycled artifacts from Buckboard Mesa, Fortymile Wash, illustrating later flake production on older discarded cores. Note characteristic scar resulting from splitting technique using direct, freehand hard hammer percussion on Reference \#264-14.

Fig. 4. Recycled artifacts from Buckboard Mesa, Fortymile Wash, illustrating older artifacts for small biface production. Reference \#556-1 is a broken Late Holocene (Gatecliff) projectile point manufactured on an older weathered artifact.

Fig. 5. Bivariate plot of obsidian hydration rim measurements on the initial flaked surface and the overlapping secondary flaked surface for secondary recycled artifacts identified at Buckboard Mesa, Fortymile Wash.

Fig. 6. Double patina on a Great Basin crescent from the Terminal Pleistocene shoreline of 26Hu-17, located in the Black Rock Desert of northwestern Nevada.

Fig. 7. Great Basin crescents recycled from Black Rock Concave Base (BRCB) projectile points showing examples of Great Basin crescents (95-4-7-11; 94-4-7-12; 95-4-13-14; 95-4-20-26), BRCB points (17-2-809; 17-2-808; 95-4-4-30; 95-4-13-05), and BRC points recycled as crescents (95-7-5-001; 96-6-9-226; 97-6-9-204; 98-8-9-098).

Fig. 8. Double patina on Early Holocene Kirk projectile points that were patinated and then reworked and incorporated in archaeological deposits of Mid-Holocene age. 
Click here to download high resolution image

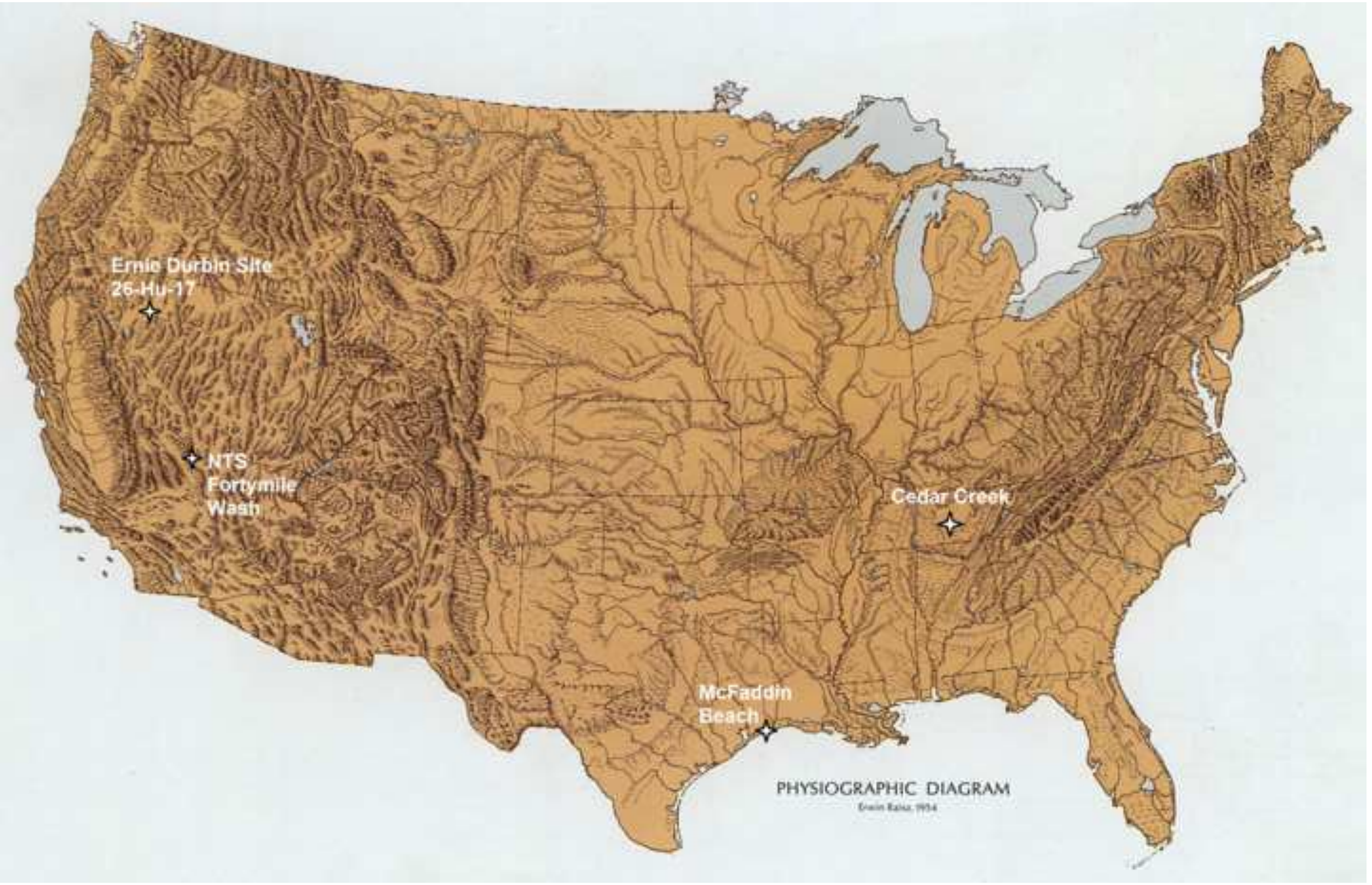


Figure 2

Click here to download high resolution image

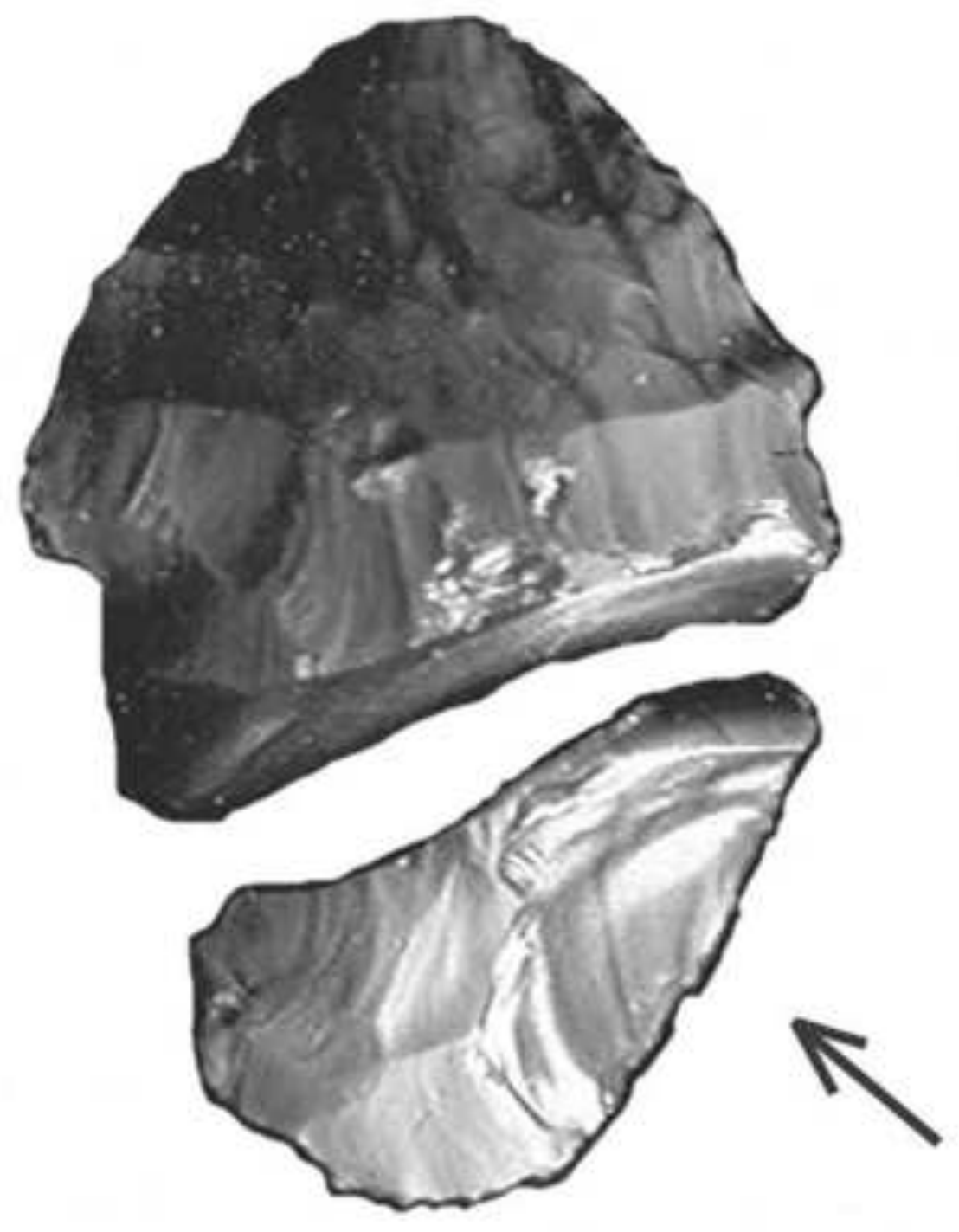

\section{$3 \mathrm{~cm}$}



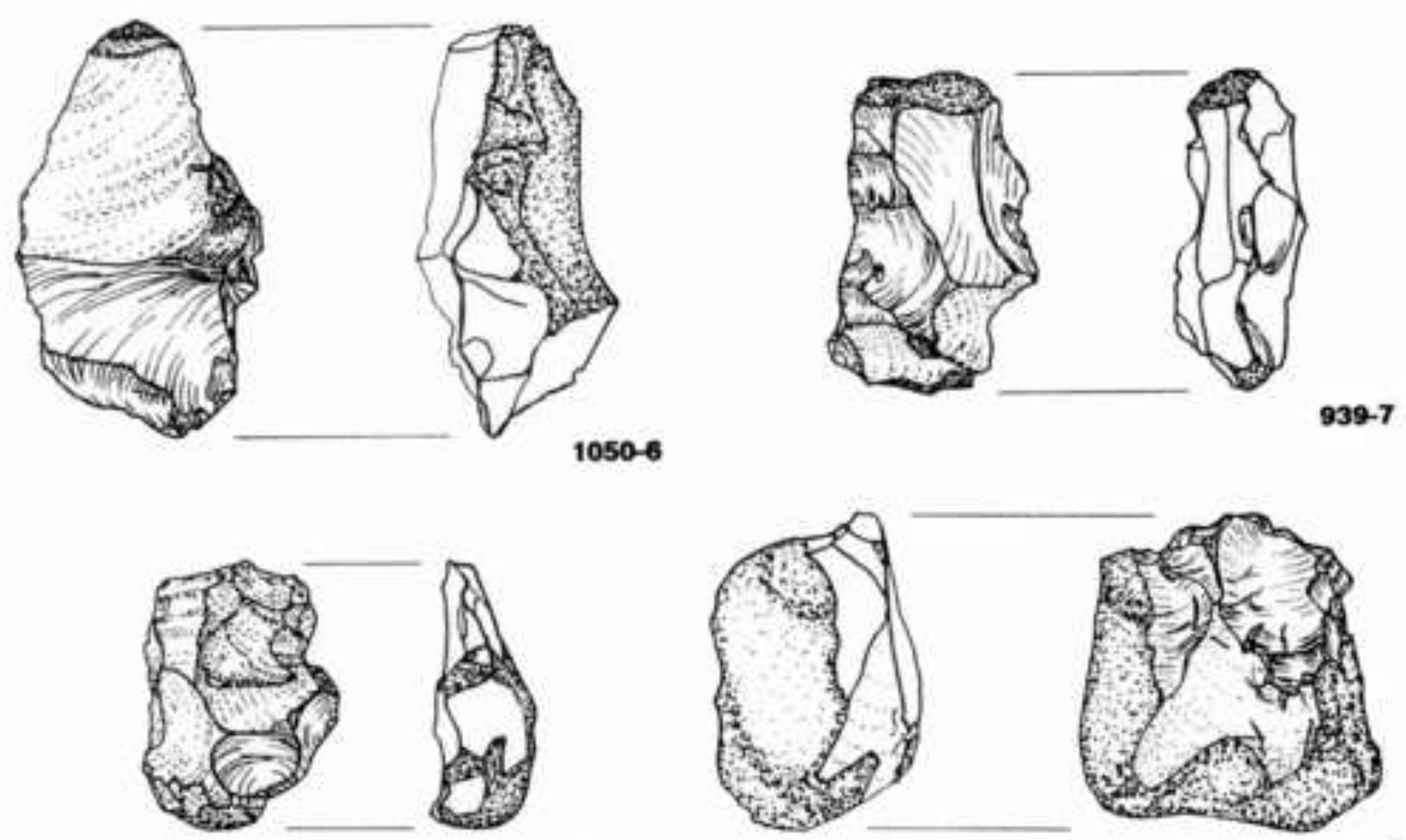

1484-4

1232-1
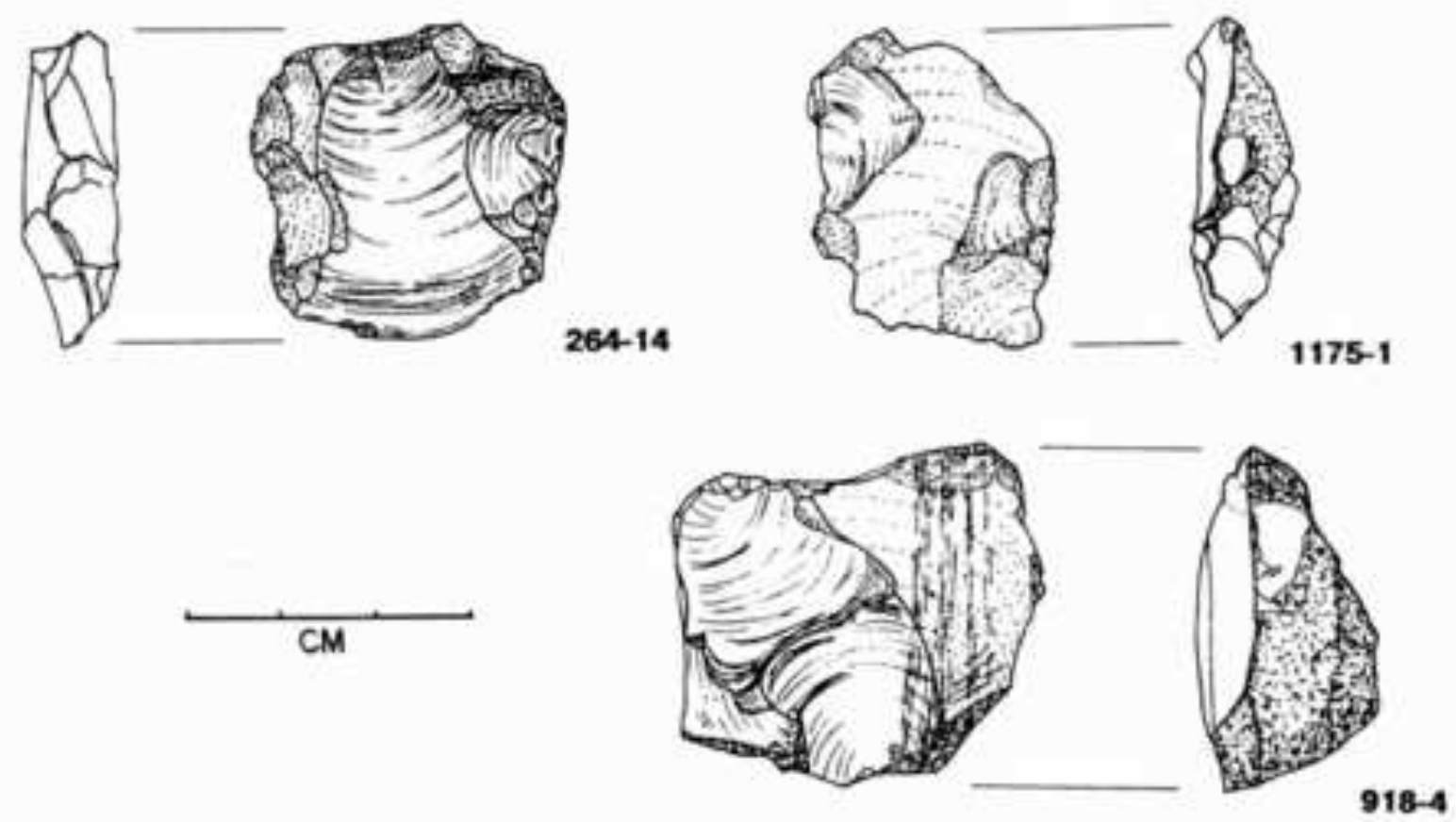


\section{Figure 4}

Click here to download high resolution image
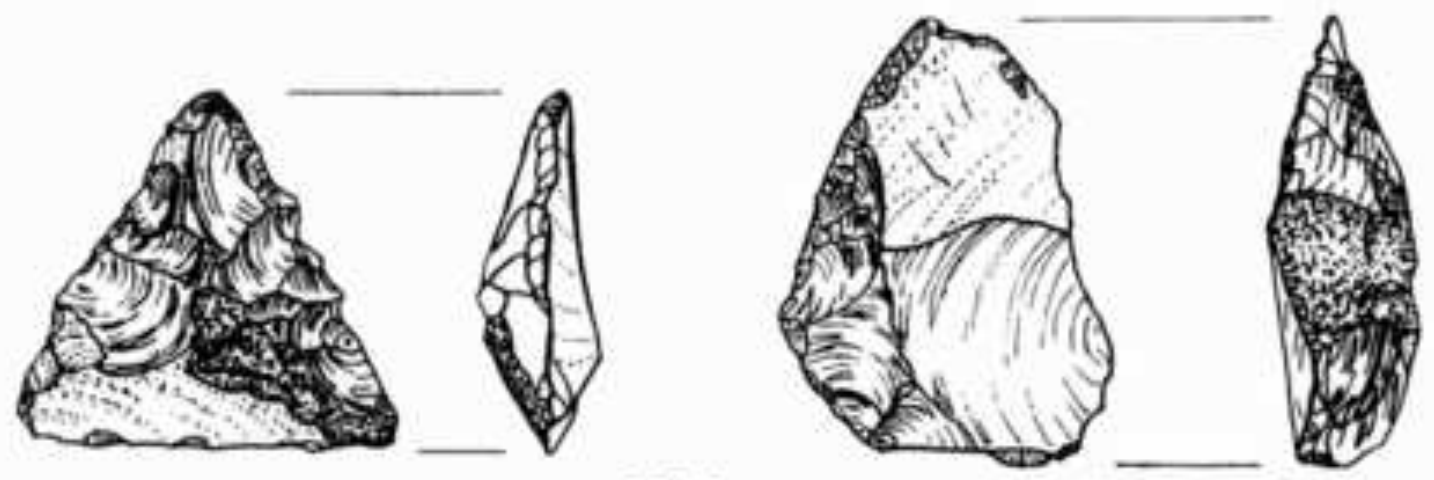

$789-7$

1217-1
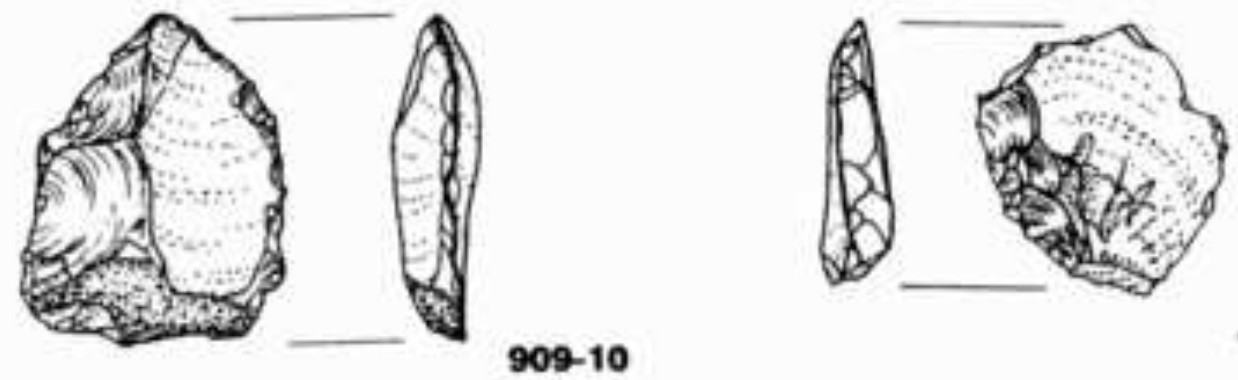

1007-5
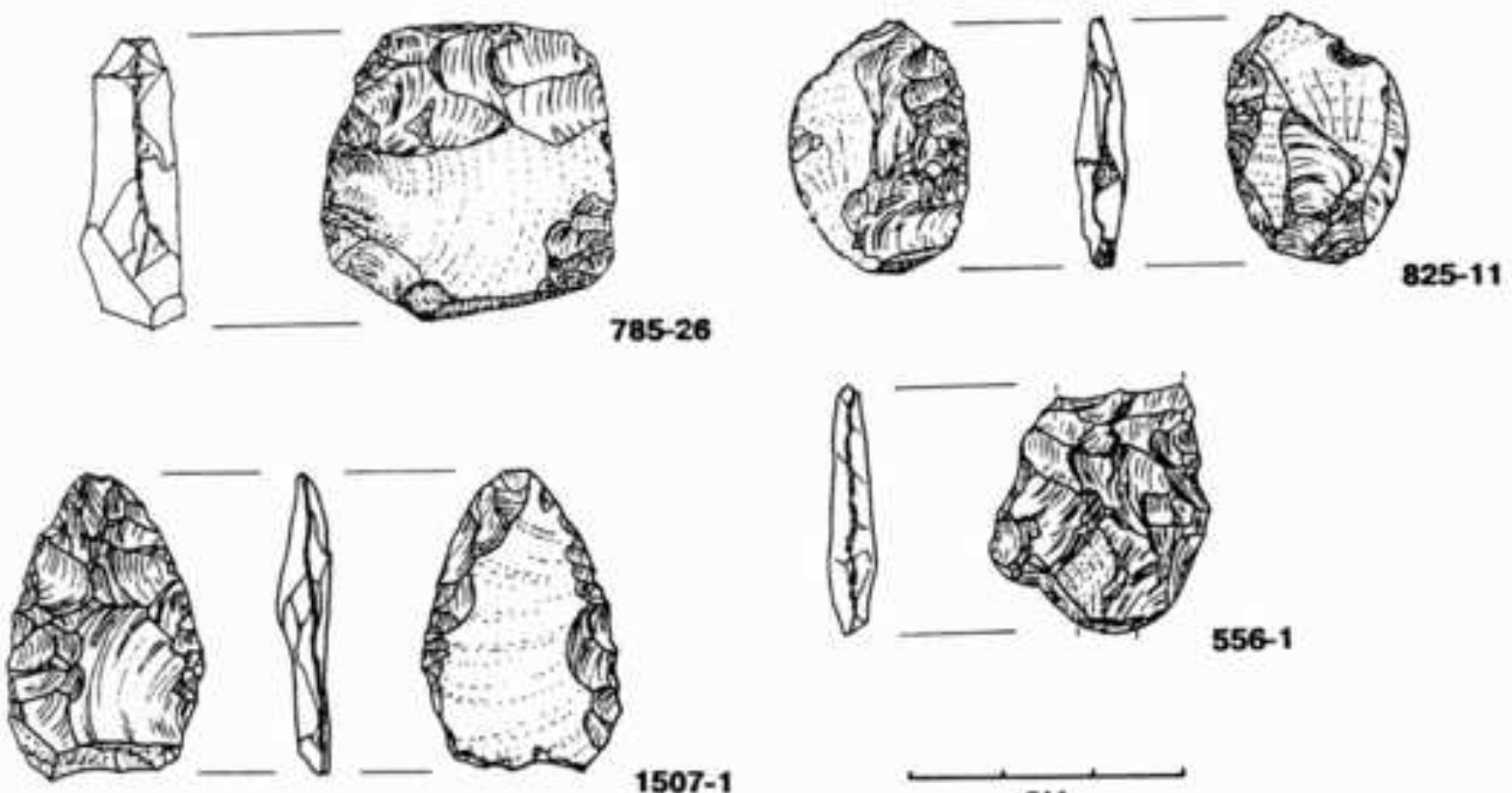

1507-1

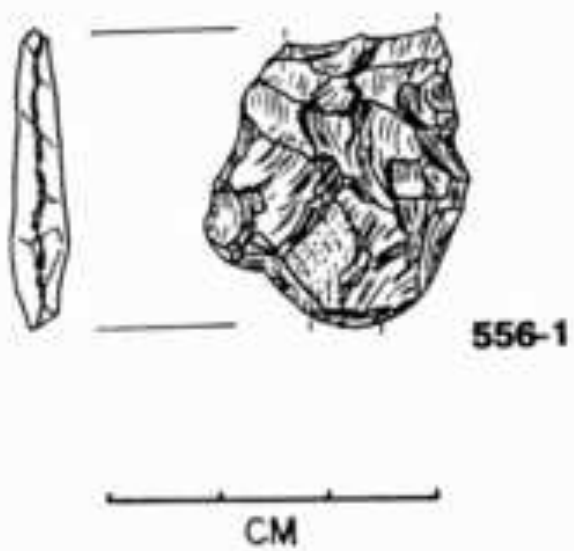


Click here to download high resolution image

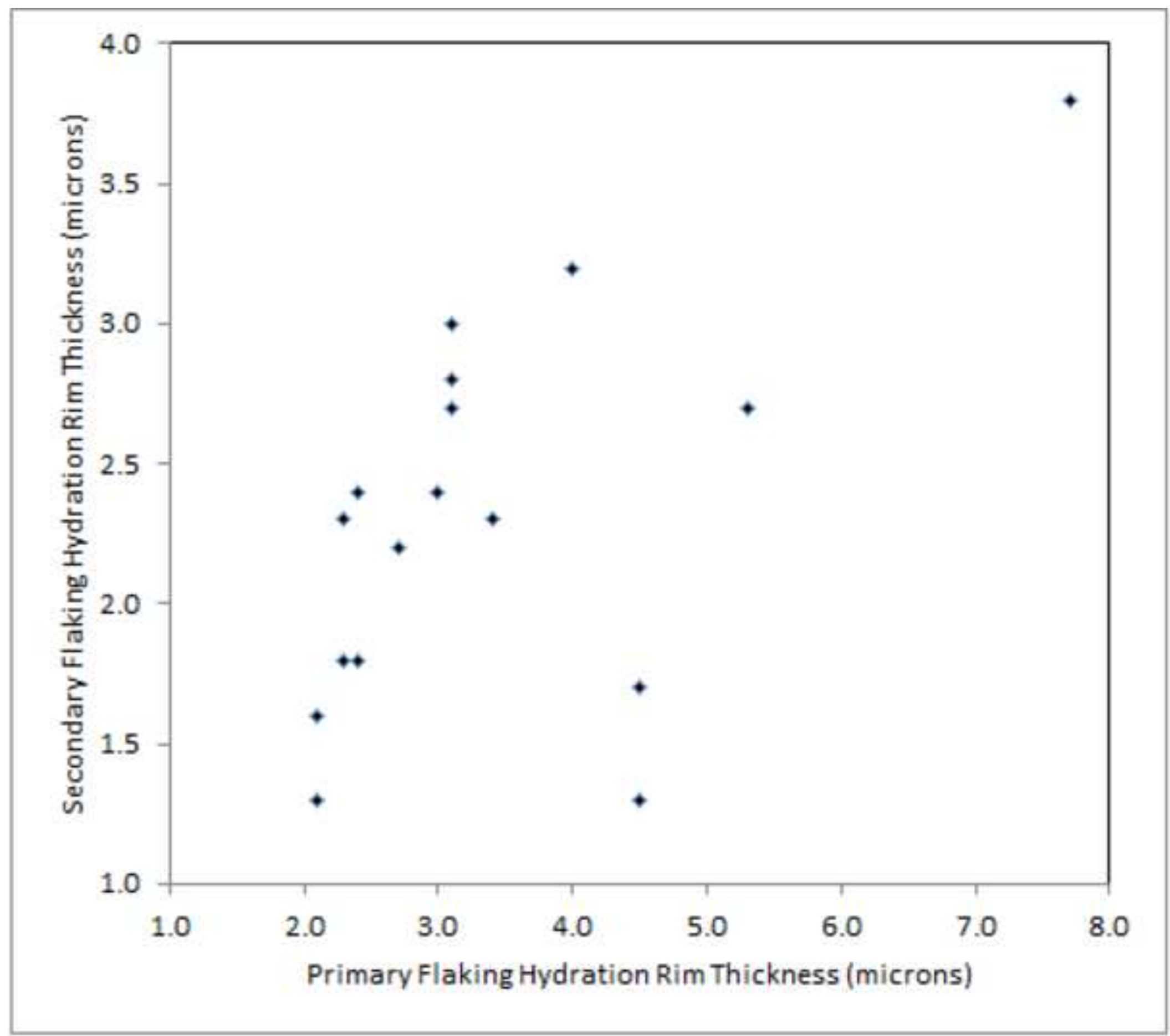




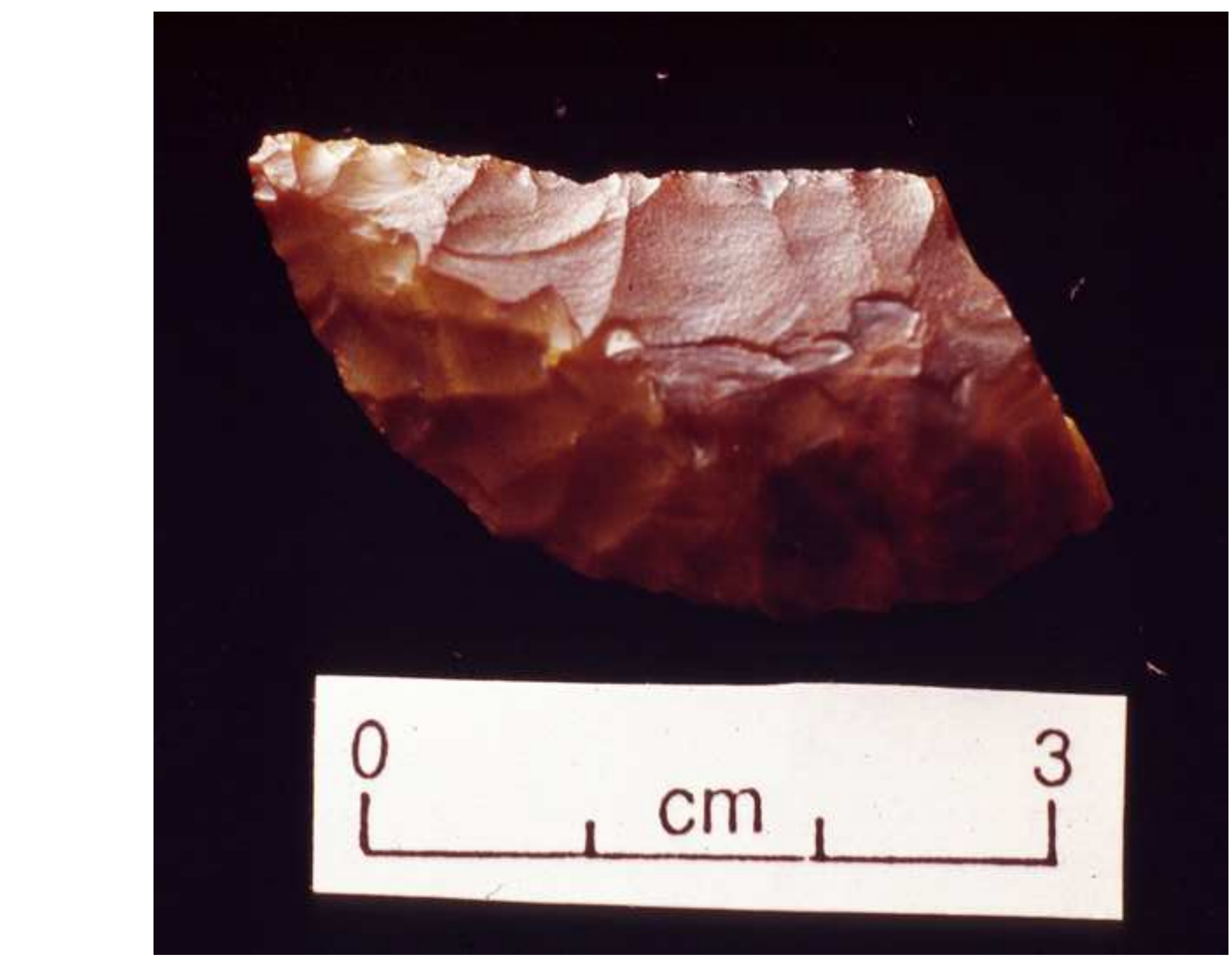

Figure 6
Click here to download high resolution image 


\section{Figure 7}

Click here to download high resolution image

$967.5-001$
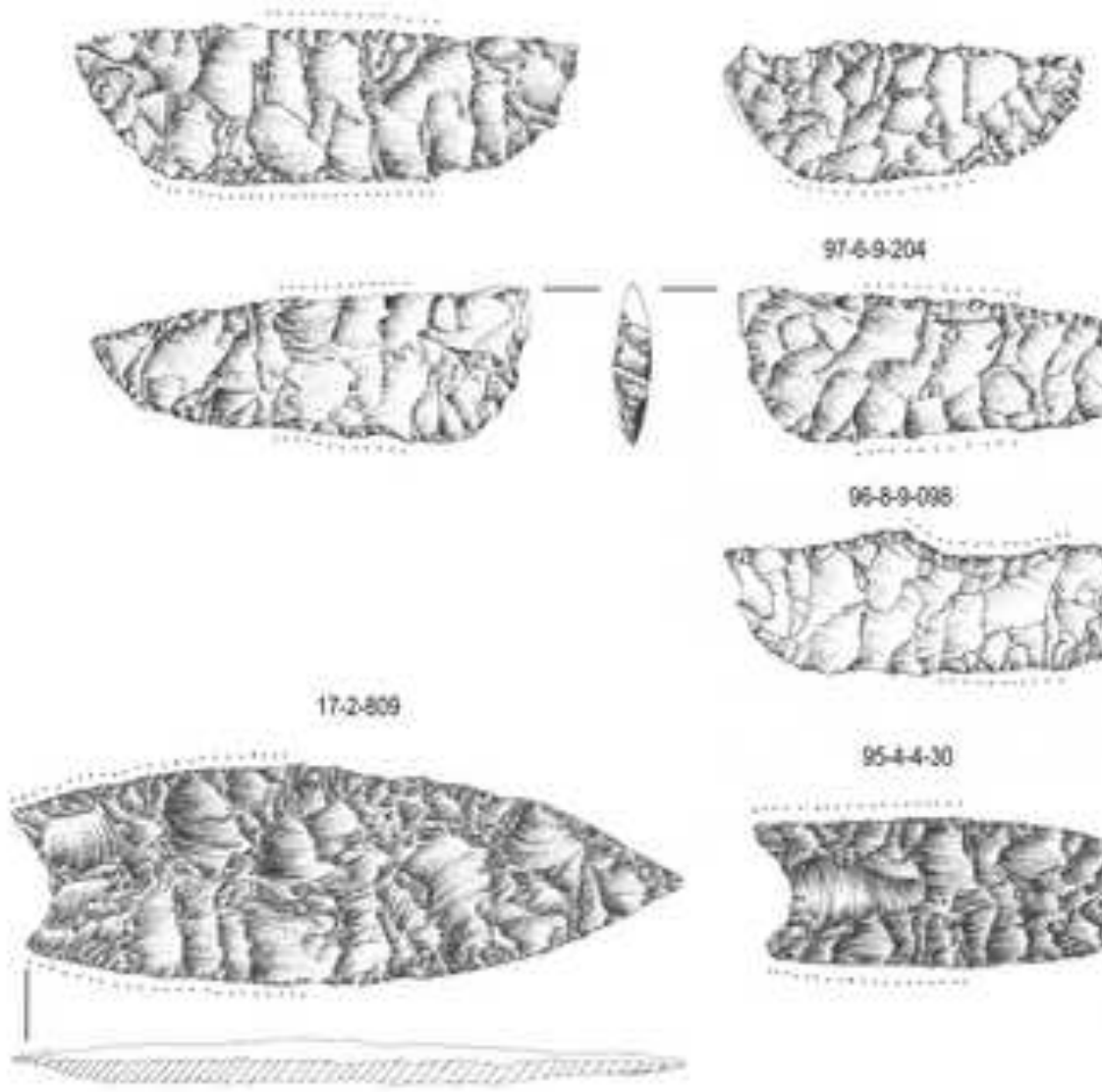

17-2-509

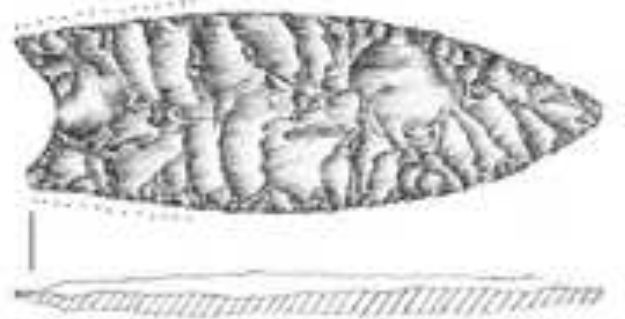

?
969204

$9759-226$

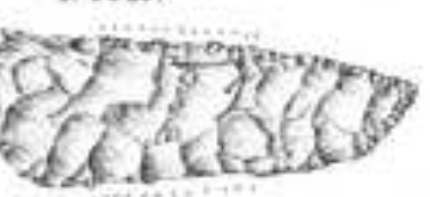

0.8-908

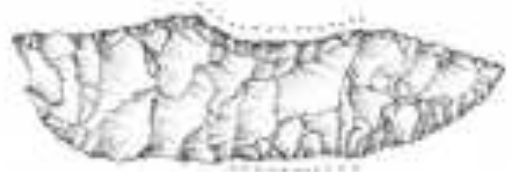

$95-4-4-20$

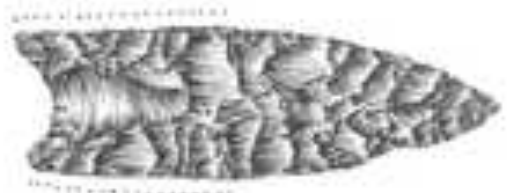

$55.4 \cdot 1360$

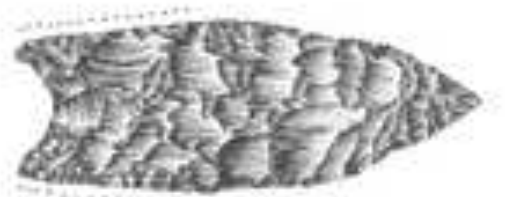

584.7.11

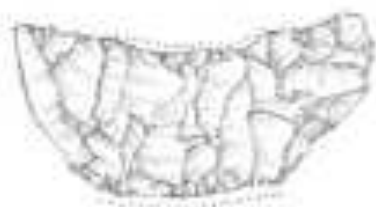

94.7 .92

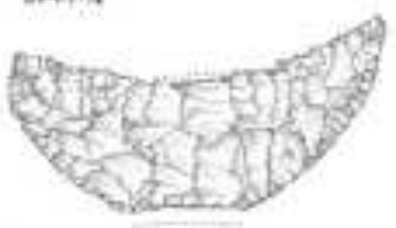

$96+13-4$

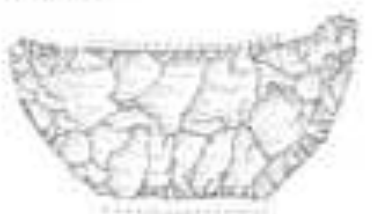

15420.21

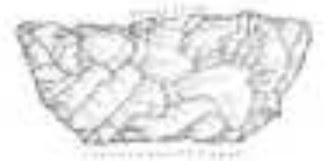


Figure 8
Click here to download high resolution image
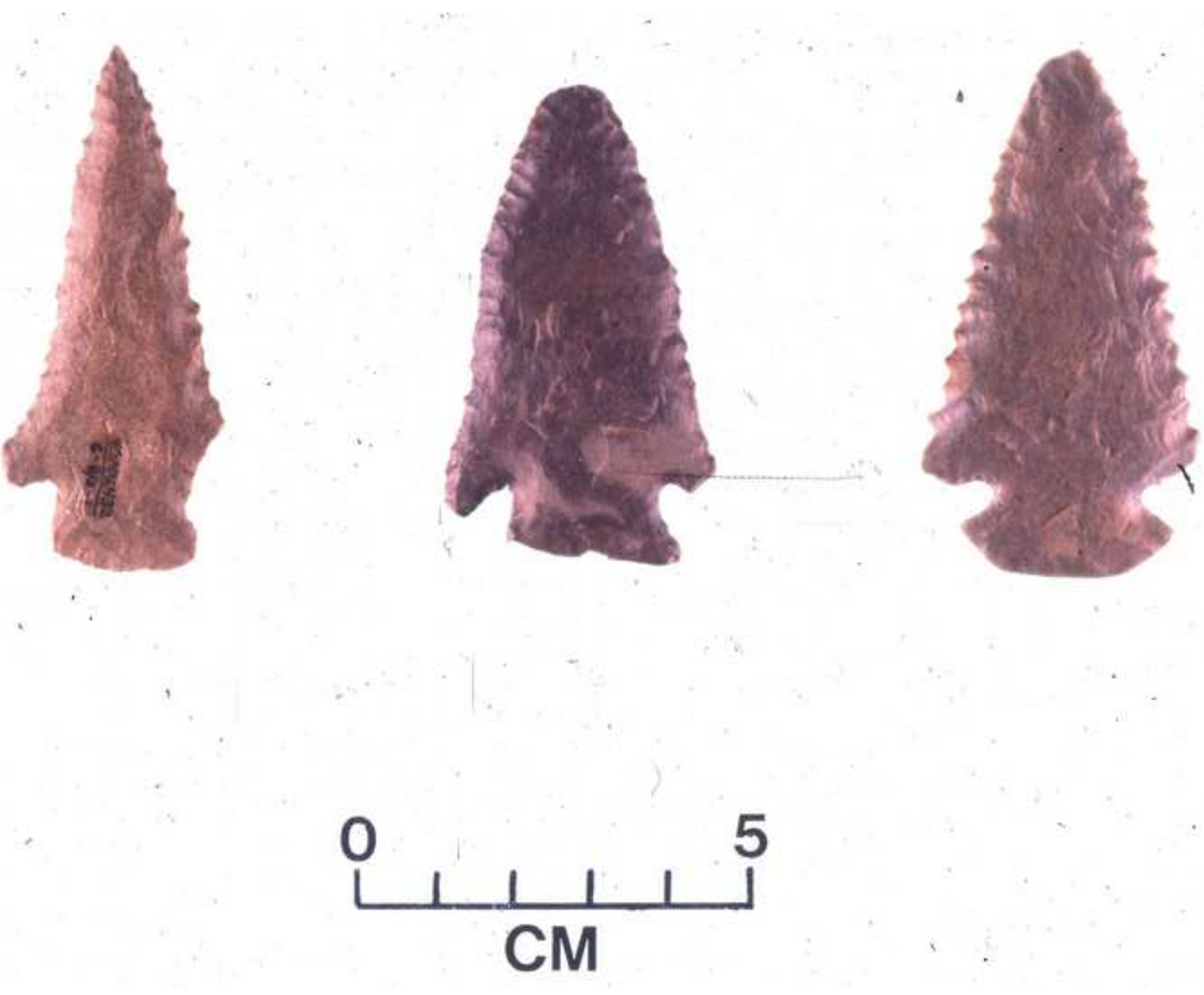


\section{Table 1}

Double patination evidence of lithic artifact reclamation in Old World assemblages.

Industry

Lower Paleolithic

Mode 1

Lower Paleolithic

Acheulian

Lower Paleolithic

Late Acheulian

Lower Paleolithic

Amudian

Middle Paleolithic

Mousterian
Fuente Nueva 3, Spain

Dealul Guran, Romania

Berekhat Ram, Israel

Fjaje, Jordan

Qesem Cave, Israel

La Quina, France

L'Ermitage, France

Abric Romaní, Spain

Hamada el-Hamra, Libya

Tipasa, Algeria

Givat Rabi East, Israel

Keoue Cave, Israel

Ein Qashish, Israel
Reference

Toro-Moyano et al. 2009

Iovita et al., 2012

Goren-Inbar, 1985

Rollefson, 1981

Barkai et al., 2009;

Gopher et al., 2005

Debenath, 1992;

Jelinek, 2013; Martin, 1906

Pradel, 1958

Vaquero, 2011

Dupree, 1965

Briggs and Hencken, 1963

Ekshtain et al., 2012

Nishiaki, 1985

Hovers et al., 2008
Middle Paleolithic

Aterian

Middle Stone Age

Upper Paleolithic

Levantine Aurignacian

Upper Paleolithic

Late Gravettian
Gebel Akhdar Hills, Libya

Jebel Gharbi, Libya

Diepkloof Rock Shelter, South Africa

el-Quseir, Palestine

Laga Velho, Portugal
McBurney and Hey, 1955

Spinapolce and Garcea, 2013

Porraz et al., 2013

Perrot, 1955

Upper Paleolithic 
Magdalenian

Late Magdalenian

Upper Paleolithic

Azilian/Federmesser

Mesolithic

Late Stone Age

Neolithic

Late Neolithic

Late Neolithic/Chalcolithic

Early Bronze Age

Historic Bedouin
Las Caldas, Spain

Molí del Salt, Spain

Belloy-sur-Somme, France Fagnart, 1991

Ballyboley, Ireland

Chapple, 2007

Kella I, Ethiopia

Endrőd, Hungary

Tabbat Hammam, Syria

Kfar Samir, Israel

Ophir Sinai Survey, Israel Moncí, Spain

Tur Imdai, Jordan
Corchón, 1993

Vaquero, et al., 2012
Chavaillon and

Berthelet, 2004

Makkay, 1992

Hole, 1959

Galilli and Weinstein-Evron, 1985

Rosen and Gopher, 2003

Harrison et al., 1994

Kujit and Russell, 1993 


\section{Table 2}

Raw material frequencies and chi-square test of raw material association for a representative sample of projectile points from the NTS in the Southern Great Basin. Early Holocene types include Clovis, Great Basin Stemmed, Pinto, and Humboldt. Late Holocene types include Large Side-Notched, Gatecliff, Elko, Eastgate, Rose Spring, and Desert Series. Observed values (O) and expected values (E) are listed.

Raw Material Type

Point Age Obsidian Non-obsidian Totals

\begin{tabular}{llll}
\hline Early Holocene & $\mathrm{O}=152$ & $\mathrm{O}=31$ & 183 \\
& $\mathrm{E}=109$ & $\mathrm{E}=74$ & \\
Late Holocene & $\mathrm{O}=218$ & $\mathrm{O}=219$ \\
& $\mathrm{E}=261$ & $\mathrm{E}=176$ & 437 \\
\hline Totals & 370 & 250 & 620 \\
\hline
\end{tabular}

Chi-square $=58.992, \mathrm{df}=1, \mathrm{p}<.00001$ 


\section{Table 3}

XRF obsidian sourcing results on a sample of projectile points from the NTS. Nonlocal sources are defined as those greater than $200 \mathrm{~km}$ away including: Kane Spring, Brown's Bench, Montezuma Range, Coso Volcanic Field, and Fish Springs. Observed values (O) and expected values (E) are listed.

\begin{tabular}{llll}
\hline & & \multicolumn{2}{l}{ Obsidian Source } \\
\cline { 2 - 3 } Point Age & Local & Nonlocal & Totals \\
\hline Early Holocene & $\mathrm{O}=41$ & $\mathrm{O}=15$ & 56 \\
& $\mathrm{E}=45$ & $\mathrm{E}=11$ & \\
Late Holocene & $\mathrm{O}=42$ & $\mathrm{O}=5$ & 47 \\
& $\mathrm{E}=38$ & $\mathrm{E}=9$ & \\
\hline Totals & & & \\
\hline
\end{tabular}

Chi-square $=4.258, \mathrm{df}=1, \mathrm{p}<.039062$ 


\section{Table 4}

Comparison of the sizes of unmodified obsidian clasts versus archaeological obsidian debitage surface collected at the Buckboard Mesa Site (26Ny4892). Laboratory size grading holds these samples constant by including only pieces larger than $0.635 \mathrm{~cm}$ square wire mesh. Column percent indicated in parentheses.

\begin{tabular}{lll}
\hline & $\begin{array}{l}\text { Unflaked } \\
\text { Obsidian } \\
\text { Clasts }\end{array}$ & $\begin{array}{l}\text { Flaked } \\
\text { Obsidian } \\
\text { Debitage }\end{array}$ \\
\hline $\begin{array}{l}\text { Size Grade } \\
\text { (one-inch) }\end{array}$ & 26 & 151 \\
$1.270 \mathrm{~cm}$ & $(.01)$ & $(.03)$ \\
$($ one-half inch) & 466 & 2972 \\
$\begin{array}{l}\text { 0.635 cm } \\
(\text { one-quarter inch) }\end{array}$ & $\begin{array}{l}(.26) \\
(.72)\end{array}$ & 2018 \\
\hline & 1765 & $(.39)$ \\
Total & & 5141 \\
\hline
\end{tabular}

Chi-square $=569.26, d f=2, p<.00001$ 


\section{Table 5}

Evidence of double patina on artifacts from the McFaddin Beach site on the coastal shelf of Eastern Texas (data adapted from Stright et al. 1999: Table 8, p. 106).

\begin{tabular}{llll}
\hline & \multicolumn{3}{c}{ Double Patina } \\
\cline { 2 - 4 } & & & \\
Point Age & Absent & Present & Totals \\
\hline Late Pleistocene/ & $\mathrm{O}=170$ & $\mathrm{O}=14$ & 184 \\
Early Holocene & $\mathrm{E}=174$ & $\mathrm{E}=10$ & \\
$\begin{array}{l}\text { Mid-Holocene/ } \\
\text { Late Holocene }\end{array}$ & $\mathrm{O}=206$ & $\mathrm{O}=7$ & 213 \\
& & $\mathrm{E}=11$ & \\
\hline Totals & 376 & 21 & 397 \\
\hline
\end{tabular}

Chi-square $=3.68, \mathrm{df}=1, \mathrm{p}<.0551$ 